\title{
International Spillovers of Monetary Policy: Evidence from France and Italy
}

\author{
Julia Schmidt ${ }^{1}$, Marianna Caccavaio ${ }^{2}$, \\ Luisa Carpinelli ${ }^{3}$ \& Giuseppe Marinelli ${ }^{4}$
}

August 2018, WP 689

\begin{abstract}
In this paper we provide empirical evidence on the impact of US and UK monetary policy changes on credit supply of banks operating in Italy and France over the period 2000-2015, exploring the existence of an international bank lending channel. Exploiting bank balance sheet heterogeneity, we find that monetary policy tightening abroad leads to a reduction of credit supply at home, in particular for US monetary policy changes. Our results show that USD funding plays an important role in the transmission mechanism, especially for French banks which rely to a larger extent on USD funding. We also show that banks adjust their euro and foreign currency lending differently, thus implying that funding sources in different currencies are not perfect substitutes. This is especially the case when tensions in currency swap markets are high, thus resulting in costly cross-currency funding.
\end{abstract}

Keywords: Spillovers, Monetary Policy, International Banking

JEL classification: E52; F42 ; G21

\footnotetext{
${ }^{1}$ Banque de France, International Macroeconomics Division, julia.schmidt@,banque-france.fr

2 Banca d'Italia, Financial Stability, marianna.caccavaio@bancaditalia.it

${ }^{3}$ Banca d'Italia, Financial Stability, luisa.carpinelli@bancaditalia.it

${ }^{4}$ Banca d'Italia, Statistical Analysis, giuseppe.marinelli@bancaditalia.it
}

This research is part of the International Banking Research Network initiative on International Spillovers of Monetary Policy. We would like to thank Julien Idier and conference participants at the Global Financial Linkages and Monetary Policy Transmission Conference for insightful comments and suggestions. The views expressed in this paper are those of the authors and do not necessarily reflect those of the Banque de France, the Banca d'Italia or the Eurosystem.

Working Papers reflect the opinions of the authors and do not necessarily express the views of the Banque de France. This document is available on publications.banque-france.fr/en 


\section{NON-TECHNICAL SUMMARY}

Monetary policy transmission to the real economy operates via various channels. One of these channels is the so-called "bank lending channel" which has been extensively studied in a domestic context. This transmission channel is specific to banks and their willingness to supply loans in response to a monetary policy change. At the same time, banks have also been identified as an important source of the international transmission of financial and real shocks, both through cross-border activities and through operations between the affiliates of globally operating banking groups. We therefore ask in this paper whether there is an international version of the bank lending channel.

How does the bank lending channel in its traditional version work? Let us consider the case of a US monetary policy tightening. Through open market operations, the US Fed sells short-term government securities in exchange for US dollars. Thus, buyers of government securities will withdraw deposits from the banking system in order to pay for the securities they purchased from the Fed. The bank lending channel, which operates on top of other transmission channels such as the interest rate channel, postulates that the drop in deposits forces banks to resort to alternative sources of financing. However, if these are limited, banks will adjust the asset side of their balance sheet, i.e. via a reduction in loan supply.

In its international version, this bank lending channel works through the exposure of French and Italian banks in terms of funding from US sources. US monetary policy tightening leads to a contraction of deposit funding for US resident banks. As a consequence, US resident banks that are not able to tap on alternative sources of funding will respond to US monetary policy tightening by reducing their cross-border loans to banks in France and Italy; this, in turn represents a funding shock for French and Italian banks, and it affects them depending on how much they rely on foreign funding from these sources.

Contrasting the experiences of France and Italy, we observe two countries within the Euro area where the international transmission of monetary policy through banks is quite different. Ex ante, the banking systems of these countries are similar in size and business model, yet they differ in the composition of funding sources and the currency composition of their funding as well as of loans granted. As shown in the below figure, French banks rely to larger extent on foreign funding, especially in USD.

We find evidence of an international bank lending channel of transmission of US monetary policy for loans to French and Italian residents over the period 2000-2015: in both countries, when US monetary policy tightens, banks that relied more intensely on US sources of funding reduced the lending to the private non-financial sector. The breakdown by currency shows that in the case of Italy the effect was concentrated on loans in EUR whereas French banks reduced their USD lending. Also, the impact is larger for French banks that relied more heavily on USD funding markets and that obtained substantial amounts of USD funds through their affiliate network in the US. Tensions in currency swap markets in recent years have exacerbated this effect. Our results are consistent with the hypothesis that funding in one currency is not a perfect substitute for funding in another currency, especially in the case of the USD.

We do not find much of an effect of UK monetary policy shocks on domestic lending in France nor Italy. Despite the fact that exposure to the UK is larger than to the US for both French and Italian banks, they seem to be isolated from UK monetary policy shocks given that most of their UK funding is not denominated in GBP. 


\section{Bank lending channel variables - Mean over 2000Q1-2015Q4}

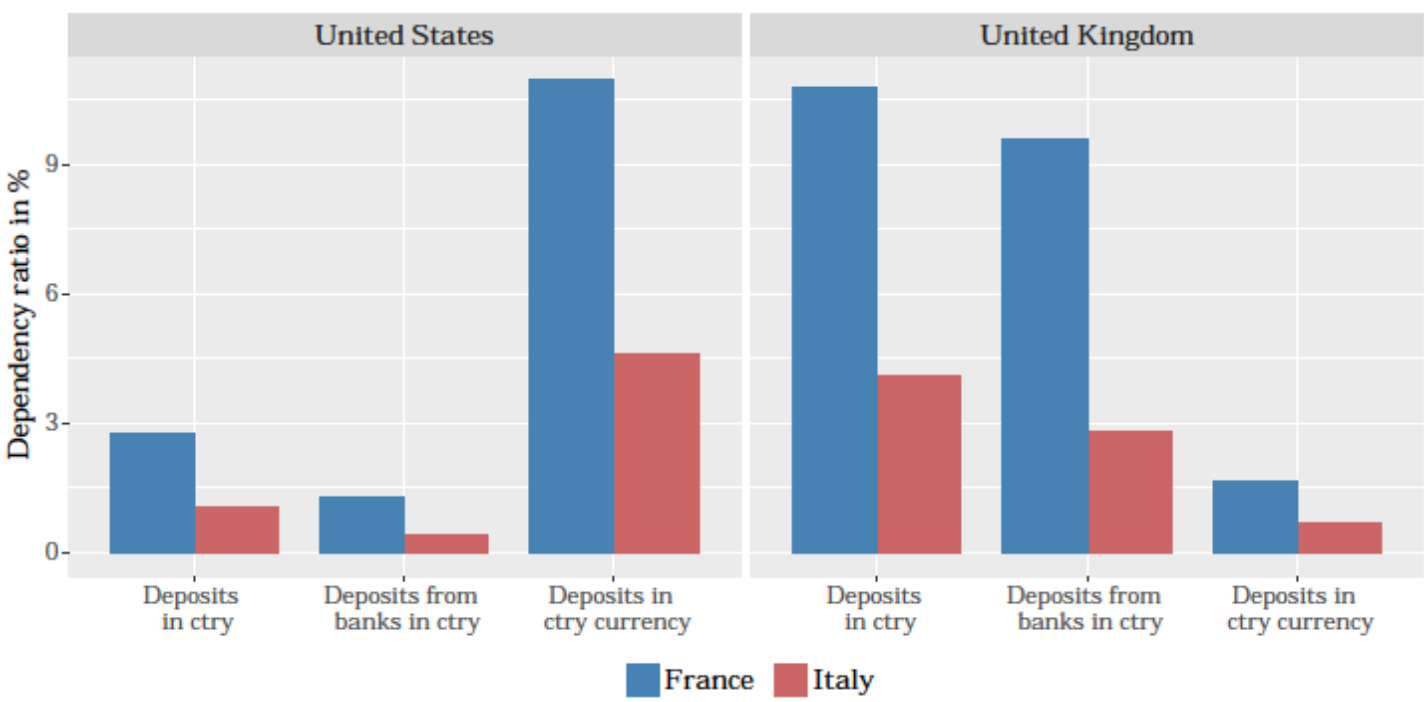

Notes: The figure shows the average shares of deposits placed by US (UK) residents for the restricted sample of French and Italian banks over the period 2000-2015. The shares are calculated as the percentage ratio of the sum of cross-border deposits over time from US (UK) residents over the total liabilities. The computation is reported also for the subset of cross-border deposits placed by US (UK) banks and for all cross-border deposits denominated in US dollars (GB pounds).

\section{La transmission internationale de la politique monétaire : une étude empirique de la France et de l'Italie}

\section{RÉSUMÉ}

Dans cette étude empirique, nous analysons l’impact de changements de politique monétaire aux États-Unis et au Royaume-Uni sur l'offre de crédit par les banques en France et en Italie pour la période 2000-2015. En particulier, nous nous intéressons à l'existence d'un «canal international du prêt bancaire ». En analysant l'hétérogénéité des bilans bancaires, nous montrons qu'un resserrement de la politique monétaire étrangère engendre une réduction de l'offre de crédit domestique, en particulier en cas de changement de la politique monétaire américaine. Le canal de transmission prépondérant est le financement par dollar américain, surtout pour les banques françaises. Nous montrons également que les banques ajustent leur offre de crédit en euro et en devises différemment, ce qui implique que les sources de financement en monnaies différentes ne sont pas de substituts parfaits. Cet effet est amplifié pendant les périodes de fortes tensions dans les marchés de swap de devises, résultant ainsi en coûts élevés du financement par monnaie étrangère.

Mots-clés : effets de débordement, politique monétaire, activités internationales bancaires

Les Documents de travail reflètent les idées personnelles de leurs auteurs et n'expriment pas nécessairement la position de la Banque de France. Ils sont disponibles sur publications.banque-france.fr 


\section{Introduction}

Global banks have been identified as an important source of the international transmission of financial and real shocks, both through cross-border activities and through operations between the affiliates of globally operating banking groups. Monetary policy transmission to the real economy operates via various channels. In this respect, there is a specific, additional role played by banks which has been extensively studied in the literature, starting from the contributions on the so-called bank lending channel. ${ }^{1}$ When financial intermediaries operate on a global scale, it is likely that the impact of monetary policy spans beyond the borders of the country where the policy is implemented and is transmitted cross-border via the activities of international banks.

This paper is part of a broader initiative of the International Banking Research Network (IBRN) as described in Buch et al. (2018). France and Italy are two interesting cases to compare. On the one hand, they are two of the largest countries of the Euro area, with financial sectors broadly comparable in size and the banking sector playing a very prevalent role in financing the real economy. ${ }^{2}$ On the other hand, the French and the Italian banking systems differ in some characteristics that could be relevant for the transmission of foreign monetary policy, namely regarding their reliance on funding sources and the currency mix of loans extended to residents.

In this paper, we investigate to what extent foreign monetary policy spills over to credit supply to the domestic economy, by looking at how changes to US and UK monetary policy affected the domestic lending of banks resident in France and Italy over the period 2000-2015. Since the transmission of shocks through the banking sector hinges crucially on banks' characteristics and balance sheet composition, we explore the possibility that lending to residents might respond differently to foreign monetary policy depending on the degree of reliance on funding from the foreign countries where monetary policy changes.

To illustrate the main mechanism, let us consider how US monetary policy changes spill over to France or Italy. This can happen through several channels, such as trade or exchange rate effects. Banks can play an additional role to the extent that they adjust their credit supply in response to US monetary policy. In its international version, this so-called "bank lending channel" works through the exposure of French and Italian banks in terms of funding from US sources. US monetary policy tightening leads to a contraction of deposit funding for US resident banks. As a consequence, US resident banks that are not able to tap on alternative sources of funding will respond to US monetary policy tightening

\footnotetext{
${ }^{1}$ See Bernanke and Blinder (1988) and Kashyap and Stein (1994).

${ }^{2}$ In both economies the domestic banking sector provides about $80 \%$ of credit to domestic non-financial corporations. See ECB (2017).
} 
by reducing their cross-border loans to banks in France and Italy; this, in turn represents a funding shock for French and Italian banks, and it affects them depending on how much they rely on foreign funding from these sources.

In this paper, we show that over the fifteen years starting in 2000, there is evidence of an international bank lending channel of transmission of US monetary policy for loans to Italian and French residents: in both countries, banks that relied more intensively on US sources of funding decreased lending to the private non-financial sector. Disaggregating domestic lending by currency, we see that in the case of Italy the effect was concentrated in loans in euro (EUR) whereas French banks reduced their foreign currency (FC) lending. In comparison to Italy, French banks relied heavily on USD funding and their affiliate network in the US which channeled USD funds to the headquarters in France. When monetary policy tightens, these funds become rare. Tensions in currency swap markets in recent years have exacerbated this effect. Our results thus show that funding in one currency is not a perfect substitute for funding in another currency, especially in the case of the USD.

We do not find any effect of UK monetary policy shocks on domestic lending in France or Italy. Though this finding might be surprising at first given the large exposures to the UK (which are considerably larger than to the US), we can explain it by the fact that most of the UK funding is not denominated in GBP, thus isolating French and Italian banks from UK monetary policy shocks.

Our results show that the economic effects of such monetary policy spillovers might be sizable. On average, the existence of a bank lending channel leads to a reduction of FC lending for French banks and of EUR lending for Italian banks. This bank lending channel is operational for banks with a high reliance on funding from US-resident sources as well as USD funding. When translating this impact into an effect on the total quantities of loans to domestic residents, the magnitude of the reduction ranges between $0.2 \%$ and $0.5 \%$. In the case of tensions in the USD/EUR swap market, the impact of US monetary policy changes for loans in USD by French banks is largely amplified.

Related literature. Pioneered with the work of Bernanke and Blinder (1988) and Bernanke and Gertler (1995), many mechanisms through which banks transmit monetary changes have been extensively studied: the bank lending channel, with its extensions related to the financial accelerator propagation (Kashyap and Stein, 1997), the portfolio rebalancing channel, the risk taking channel (Adrian and Shin, 2008; Jiménez et al., 2014) or the signalling channel (Bauer and Rudebusch, 2014). Our question of whether monetary policy exerts its effects beyond national borders by modifying the lending supply of banks that operate on a global scale sets our paper in the vast realm of the international dimension of the transmission mechanisms of monetary policy. 
This paper relates to the literature that uses bank-level and loan-level data to trace out the impact of foreign monetary policy shocks on domestic lending (as well as the transmission of domestic monetary policy changes on foreign lending). Morais et al. (2017) find that European, UK and US affiliates in Mexico adjust credit to Mexican firms in response to their home countries' monetary policies. Cetorelli and Goldberg (2012) show that, during the Great Financial Crisis, banks which managed liquidity on a global scale and which relied on cross-border internal funding were able to shield their operations from the changes in monetary policy more than banks that operate on a small, regional scale.

This paper is also specifically related to the literature on foreign currency funding and in particular the impact of USD funding shocks on bank lending. Ivashina et al. (2015) show that USD lending by European banks contracted in response to tensions in USD wholesale funding markets as European banks were not able to fully substitute the decrease in USD funding with EUR funding. Ongena et al. (2017) show that foreign currency lending is more responsive to foreign monetary policy than is home currency lending, thus implying that lending in foreign currencies gives room to an international bank lending channel. A similar point is made by Takats and Temesvary (2017).

Correa et al. (2017) use the Locational Banking Statistics from the BIS to show that domestic monetary policy leads to changes in cross-border bank flows; they find evidence of a cross-border bank lending channel as well as what they term a "portfolio channel" where the deterioration of borrowers' net worth due to monetary policy tightening leads banks to shift credit supply to foreign borrowers. Demirguc-Kunt et al. (2017) find that expansive monetary policy exerts a positive effect on cross-border syndicated lending from the country where monetary policy is relaxed; the impact is mitigated by the presence of foreign banks in the destination country of loans. Bruno and Shin (2015) find that a tigher US monetary policy leads to a decline in the leverage of international banks and to lower cross-border banking capital flows, in association with an appreciation of the US dollar. Aizenman et al. (2016) look at the reaction of financial conditions of emerging and developing economies (EDEs) to various movements of center economies (US, Euro area, Japan and China), including their monetary policy stance and find that these have been a predominant driver of fluctuations in financial variables in EDEs.

Recently, a growing literature has looked at the potential international spillovers of unconventional measures undertaken by the central banks of the largest world economies, with a particular focus on the US and the Euro area. To name a few examples, McCauley et al. (2015), Georgiadis (2015), Aizenman et al. (2016), Bhattarai et al. (2015) and Fratzscher et al. (2013) show that the Fed's quantitative easing programme can be associated with spillovers to other countries' asset prices, exchange rates or financial flows in general. In a 
similar vein, various papers have examined the degree of international spillovers associated with the recent ECB actions. Among others, Fratzscher et al. (2016), Falagiarda et al. (2015) and Bluwstein and Canova (2016) show that the ECB's unconventional monetary policies have spilled over to foreign asset markets, including credit markets.

The rest of this paper is organized as follows. Section 2 describes the methodological challenges and the empirical specification. In section 3, we present the data and stylized facts of the French and Italian banking systems. Section 4 presents the results of our analysis while section 5 concludes.

\section{Methodology}

Before describing the methodology, we lay out a few definitions. We use data collected for French and Italian banks, by which we mean banks resident in France and Italy, including those that are of foreign nationality (i.e. branches and subsidiaries of foreign banking groups). The data are collected at the bank-level for the French sample and at the grouplevel with separate details for the domestic and foreign components for the Italian sample. The banks in our sample raise cross-border deposits from foreign residents. Our identification strategy, which we describe in detail below, uses these cross-border deposits to identify the bank-specific supply shocks. We also use details on cross-border loans to single out some stylized facts and to compare the behavior of cross-border loans and cross-border deposits.

Our dependent variable is domestic loans by which we mean loans extended by French and Italian banks to French and Italian residents. Whenever we refer to a bank's balance sheet item without specifying whether it is domestic (with respect to residents) or crossborder (with respect to non-residents), i.e. assets or loans, we mean the entire balance sheet, i.e. the sum of domestic and cross-border assets or loans. In terms of counterparties, we distinguish not only between residents and non-residents, but also between the private non-financial and financial sector, the latter comprising banks and non-banks.

Monetary policy is transmitted internationally via various channels, such as changes in exchange rates, which induce changes in financial and trade flows, changes in interest rates, which affects external demand, or banks' foreign activities. We are interested in the last channel. Our objective is therefore to identify supply shifts that are driven by a change in banks' willingness or ability to lend following a monetary policy change. Also, we have to isolate such supply shocks from simultaneous demand effects, stemming from the general macroeconomic environment, including the effects of monetary policy. The identification therefore consists in obtaining bank-specific shocks by determining to which extent a bank can insulate its portfolio from monetary policy shocks. 
To this aim, in order to explore how foreign monetary shocks operate via the activity of internationally active banks, one has to identify variables in banks' balance sheets that are likely candidates to transmit the shocks across borders. The regression approach therefore consists in interacting bank balance sheet characteristics $\left(\right.$ Channel $\left._{b, t-k-1}\right)$ with a measure of monetary policy $(\triangle M P)$ :

$$
\begin{aligned}
\Delta Y_{b, t} & =\alpha_{0}+\sum_{k=0}^{K}\left(\sum_{c t r y} \alpha_{1, k}^{c t r y} \cdot \Delta M P_{t-k}^{c t r y} \cdot \text { Channel }_{b, t-k-1}^{c t r y}\right)+\sum_{c t r y} \alpha_{2}^{c t r y} \text { Channel }_{b, t-k-1}^{c t r y} \\
& +\alpha_{3} X_{b, t-1}+f_{b}+\eta_{t}+\varepsilon_{b, t}
\end{aligned}
$$

where $X_{b, t-1}$ is a vector of lagged bank balance sheet controls, such as size, capitalization, share of liquid assets and core deposits. ${ }^{3}$ The inclusion of bank fixed effects $f_{b}$ as well as bank controls $X_{b, t-1}$ allow to control for time-invariant unobservable and time-varying bankspecific observable supply factors; to properly isolate any aggregate country-level cyclical component of demand and supply we include time fixed effects $\eta_{t}$. Standard errors are clustered at the bank-level.

For the coefficient $\alpha_{1, k}^{c t r y}$ to be unbiased, we need all remaining bank-specific demand and supply shocks to be uncorrelated to the identified shock $\Delta M P_{t-k}^{\text {ctry }} \cdot$ Channel $_{b, t-k-1}^{\text {ctry }}$. We argue that this is the case as foreign monetary policy that is transmitted to French and Italian banks via the different channel variables is unlikely to be correlated with bankspecific supply shocks such as domestic regulation or bank-specific demand shocks arising from a bank's client base.

We want to stress that a potential correlation of US or UK monetary policy with ECB monetary policy is not a concern for our identification strategy. First of all, as we will show below, there does not seem to be much correlation between the Euro area monetary policy and the two foreign monetary policies that we analyze. Furthermore, we are not looking at the coefficient of $\Delta M P_{t-k}^{c t r y}$, but at the interaction of $\Delta M P_{t-k}^{c t r y}$ and a bank-specific variable. As a corollary, we are able to include monetary policy changes derived from the nominal (shadow) interest rate and do not need to resort to Taylor residuals or structural shocks.

Dependent variable. We are interested in how monetary policy shocks transmit to the real economy and therefore concentrate on loans to the non-financial sector (or to the nonbank sector if such a distinction is not feasible, thus including financial non-bank institutions in this measure). Lending to the public sector is thus excluded. We specifically want to differentiate between foreign currency loans and loans in domestic currency and therefore disaggregate our data by the respective currency.

\footnotetext{
${ }^{3}$ In the case of the French data, we also include intra-group funding as a control variable.
} 
Bank lending channel. We use data on banks' cross-border deposits from a given country (ctry) to quantify to what extent banks rely on funding from this country. The lagged value of this variable (scaled by total assets) is interacted with changes in monetary policy in order to identify the bank-specific funding shock. Our conjecture is that banks will be affected by foreign monetary policy to a larger degree if they rely more heavily on foreign funding. We consider overall cross-border deposits from residents in country ctry, but we also specifically look at deposits from banks (thus capturing shock transmission via interbank markets and internal capital markets within banking groups). As a third variable for Channel $_{b, t-k-1}^{\text {ctry }}$, we consider deposits denominated in the currency of ctry as a country's monetary policy specifically affects the money supply in the respective home currency. Note that deposits in ctry currency are deposits from all non-residents, both in ctry as well as other countries.

The dependence on foreign funding identifies the first step in the transmission of foreign monetary policy changes to the domestic loan supply of French and Italian banks. This foreign funding dependence represents a friction which will constrain banks' lending supply as long as the concerned banks cannot tap on other sources of funding (for example domestic wholesale markets). As a consequence, the effect we measure is the average response of French and Italian banks to foreign monetary policy changes due to their dependence on foreign funding, not conditioning on the question whether they mobilize other domestic sources of funding or not.

We are interested in monetary policy spillovers from large economies which conduct their monetary policy independently of other countries. In the framework of the IBRN project on monetary policy spillovers, transmission from the Euro area, the US, Japan and the UK are analyzed. In this contribution, we exclude the Euro area (as France and Italy are among the largest economies in the Euro area and it therefore would be difficult to claim that the monetary policy changes are exogenous) as well as Japan. For monetary policy to spill over to French and Italian banks' resident lending, we need sufficiently large exposures to the economies putting in place monetary policy changes.

Table 1 shows that French banks are mainly exposed to the UK and the US. ${ }^{4}$ Italian banks, on the other hand, are mainly exposed to Euro area countries, the United Kingdom and the United States. Japan is not an important deposit source or loan destination for French banks and even less so for Italian banks. It is for this reason that we concentrate on monetary policy shocks coming from the United Kingdom and the United States, thus implying ctry $=(\mathrm{US}, \mathrm{UK})$.

\footnotetext{
${ }^{4}$ French banks' exposures to Switzerland are also quite substantial, however, we do not consider spillovers from Swiss monetary policy changes as the Swiss economy is very open and reacts to external economic shocks, stemming notably from the Euro area, its largest trade partner. In addition, Swiss monetary policy, at least since the Great Financial Crisis, is centered around the exchange rate and thus different in nature from Euro area, US, UK and Japanese monetary policy.
} 
Table 1: Ranking of country exposures (shares in \%)

\begin{tabular}{|c|c|c|c|c|c|c|c|}
\hline \multicolumn{4}{|c|}{ France } & \multicolumn{4}{|c|}{ Italy } \\
\hline Rank & Country & Deposits & Loans & Rank & Country & Deposits & Loans \\
\hline 1 & United Kingdom & 26.3 & 25.1 & 1 & Germany & 22.9 & 21.7 \\
\hline 2 & United States & 13.3 & 12.6 & 2 & United Kingdom & 18.5 & 12.5 \\
\hline 3 & Switzerland & 8.1 & 4.9 & 3 & France & 11.7 & 8.5 \\
\hline 4 & Germany & 7.8 & 9.6 & 4 & Austria & 7.5 & 8.2 \\
\hline 5 & Luxembourg & 7.4 & 4.0 & 5 & Luxembourg & 5.2 & 2.9 \\
\hline 6 & Belgium & 5.7 & 4.1 & 6 & United States & 4.4 & 4.1 \\
\hline 7 & Italy & 4.3 & 6.6 & 7 & Poland & 3.2 & 4.2 \\
\hline 8 & Hong Kong & 3.6 & 1.2 & 8 & Spain & 2.4 & 4.4 \\
\hline 9 & Japan & 3.5 & 4.7 & 9 & Croatia & 1.9 & 3.4 \\
\hline 10 & Spain & 3.2 & 5.2 & 10 & Switzerland & 2.2 & 1.8 \\
\hline
\end{tabular}

Notes: This table provides the average share of cross-border deposits (loans) by counterparty country for French and Italian banks for the sample period (2000-15). The shares are calculated as the percentage ratio of the sum of deposits (loans) from (to) a specific country over the total sum of deposits (loans) from (to) non-residents. A comprehensive description of the variables can be found in table 7 .

Monetary policy. Over the time period under consideration (2000-2015), monetary policy in major advanced economies was impaired by the zero lower bound. In order to capture the monetary stance, we rely on the shadow rate as a measure of monetary policy, which is provided by Krippner (2016). In times of conventional monetary policy, the shadow rate is in line with the nominal policy rate (see figure 1 which compares the policy rates and shadow rates for the US and UK, along with the ones for the Euro area). During times of the zero lower bound, it captures unconventional monetary policies such as quantitative easing or liquidity support to banks. Figure 1 shows that the shadow rate for the US and UK are actually quite different from the Euro area shadow rate, especially in the aftermath of the Great Financial Crisis as the ECB implemented its large-scale asset purchasing programme years after quantitative easing was implemented by the US Fed and the Bank of England respectively. These differences further weaken any concerns about omitted variable bias. 


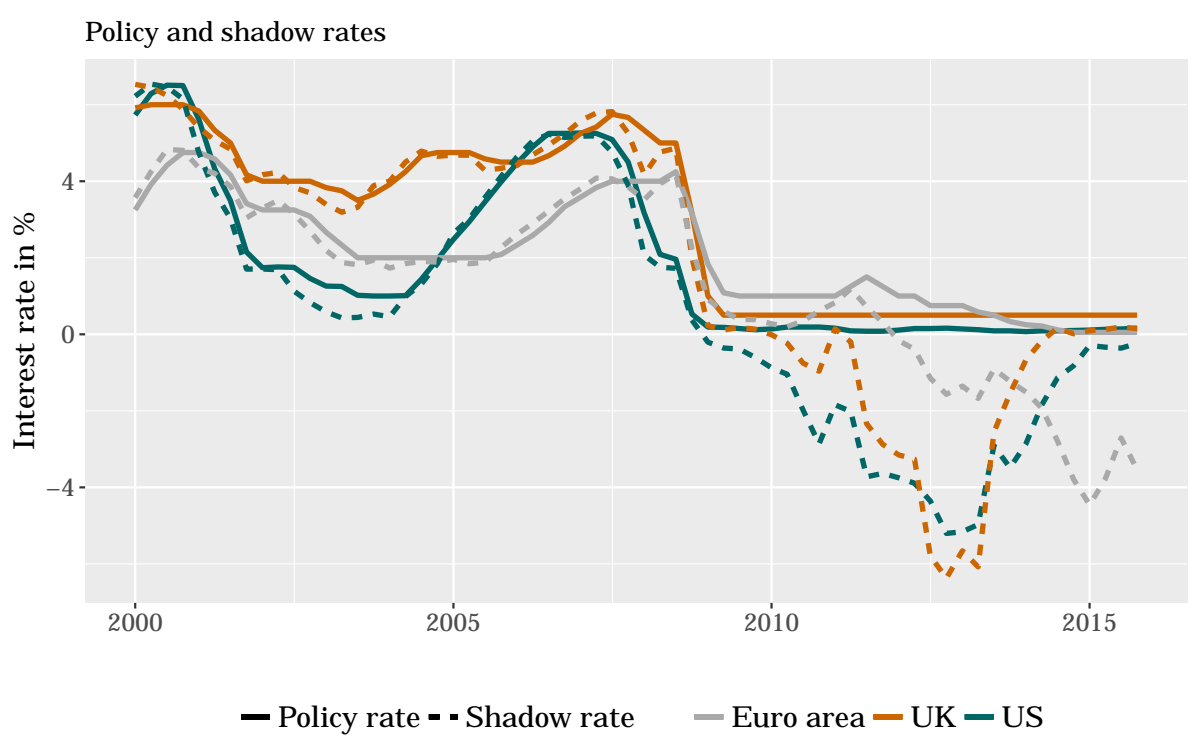

Notes: This figure shows the central bank monetary policy rate and the Krippner (2016) monetary shadow policy rate for Euro area, US and UK over the period 2000-2015.

The bank lending channel is tightly related to funding costs for banks, but it is more subtle than simply equating funding costs with the nominal policy rate which is why we make use of the shadow rate. The bank lending channel in its conventional version assumes that banks experience a drop in deposits (aggregate money supply drops) whenever monetary policy tightens. The drop in deposits following a monetary policy tightening cannot be substituted without costs by other sources of funding due to frictions violating the Modigliani-Miller theorem. As a consequence, banks have to adjust the asset side of their balance sheet. During the period of the zero lower bound, the existence of a bank lending channel need not be impaired: as long as unconventional monetary policies affects the money supply and thus the supply of deposits to banks (which they sure do given the large magnitudes of central bank asset purchases and liquidity support to banks), a bank lending channel can be at work. Thus, while changes in the shadow rate do not imply changes in short-term funding rates as is the case during periods of conventional monetary policy, the shadow rate captures changes in funding supply to banks during periods of unconventional monetary policy. The bank lending channel concerns exactly these funding supply shocks, both in its traditional version when brought about by changing interest rates or in its unconventional version when brought about by the expansion of central bank balance sheets. 


\section{Data and stylized facts on the French and Italian banking systems}

We employ bank-level data collected respectively by the Banque de France and the Autorité de Contrôle Prudentiel et de Résolution and by the Bank of Italy in its Supervisory and Statistical Reports. Balance sheet data are collected for the purpose of supervision and regulatory reporting at quarterly frequency. The data on loans and deposits disaggregated by residence of the counterparty and currency of denomination are collected for the purpose of the construction of the International Banking Statistics of the Bank for International Settlements. A second part of the data set comes from an IBRN cross-country database with a set of monetary policy interest rate indicators from which we take the shadow rate of monetary policy as provided by Krippner (2016). Our sample covers the period from 2000 to 2015.

\section{Table 2: Summary statistics}

(a) France

\begin{tabular}{|c|c|c|c|c|c|c|}
\hline \multirow[b]{2}{*}{ Variable } & \multicolumn{3}{|c|}{ Full sample } & \multicolumn{3}{|c|}{ Restricted sample } \\
\hline & $\mathrm{N}$ & Mean & $\mathrm{Sd}$ & $\mathrm{N}$ & Mean & $\mathrm{Sd}$ \\
\hline Total assets (bn EUR) & 54000 & 8.57 & 53.01 & 7096 & 28.16 & 119.83 \\
\hline Loans/assets & 53992 & 40.86 & 33.4 & 7088 & 51.37 & 24.75 \\
\hline Loans to non-fin. sector/total loans & 52276 & 54.58 & 42.77 & 7089 & 82.8 & 19.47 \\
\hline Loans to resident non-fin. sector/loans to non-fin. sector & 39071 & 88.38 & 25.14 & 7084 & 68.93 & 31.91 \\
\hline FC share of loans to resident non-fin. sector & 38798 & 3.14 & 11.78 & 7039 & 9.02 & 17.35 \\
\hline FC share of loans to non-resident non-fin. sector & 23857 & 21.6 & 32.33 & 6614 & 39.91 & 34.22 \\
\hline Cross-border loans US/total assets & 53991 & 0.48 & 2.81 & 7087 & 2.02 & 4.63 \\
\hline Cross-border loans UK/total assets & 53991 & 1.67 & 7.44 & 7087 & 6.89 & 12.57 \\
\hline Cross-border deposits US/total assets & 53992 & 0.66 & 3.93 & 7088 & 2.92 & 7.91 \\
\hline Cross-border deposits UK/total assets & 53981 & 1.98 & 8.53 & 7080 & 10.98 & 19.03 \\
\hline
\end{tabular}

(b) Italy

\begin{tabular}{|c|c|c|c|c|c|c|}
\hline \multirow[b]{2}{*}{ Variable } & \multicolumn{3}{|c|}{ Full sample } & \multicolumn{3}{|c|}{ Restricted sample } \\
\hline & $\mathrm{N}$ & Mean & $\mathrm{Sd}$ & $\mathrm{N}$ & Mean & $\mathrm{Sd}$ \\
\hline Total assets (bn EUR) & 41441 & 4.84 & 43.74 & 11271 & 16.49 & 82.74 \\
\hline Loans/assets & 40600 & 69.70 & 14.94 & 11024 & 70.89 & 20.14 \\
\hline Loans to non-fin. sector/total loans & 40578 & 78.23 & 23.57 & 11050 & 62.16 & 32.03 \\
\hline Loans to resident non-fin. sector/loans to non-fin. sector & 24939 & 97.57 & 10.33 & 11030 & 92.53 & 17.43 \\
\hline FC share of loans to resident non-fin. sector & 39889 & 1.03 & 3.74 & 10570 & 2.15 & 6.35 \\
\hline FC share of loans to non-resident non-fin. sector & 23455 & 9.58 & 23.35 & 7464 & 21.89 & 30.99 \\
\hline Cross-border loans US/total assets & 40542 & 0.09 & 1.12 & 11032 & 0.30 & 2.09 \\
\hline Cross-border loans UK/total assets & 40537 & 0.64 & 4.35 & 11037 & 2.29 & 8.07 \\
\hline Cross-border deposits US/total assets & 40542 & 0.13 & 1.94 & 11042 & 0.45 & 3.70 \\
\hline Cross-border deposits UK/total assets & 40536 & 1.88 & 10.99 & 11046 & 5.76 & 18.36 \\
\hline
\end{tabular}

Notes: This table reports summary statistics for bank-level data obtained from the Banque de France/ACPR and from Banca d'Italia/Supervisory reports. The data is quarterly for the period 2000Q1-2015Q4. Panel a describes the sample for French banks and panel b the one for Italian banks. Both the summary statistics of all reporting banks (full sample) as well as the one for the restricted sample used for the regression analysis are displayed. For French banks, the sample is restricted to those banks that lend at least $10 \%$ of their assets to the non-financial sector and have at least $1 \%$ of their total assets in loans or deposits in either the UK or US. For Italian banks, the sample is restricted to those banks that lend at least $2 \%$ of their total assets to foreign residents. The variable Loans refers to loans extended by the banks in the sample, the variable Deposits is represented by deposit liabilities of the banks in the sample. 


\subsection{France}

The French banking system is highly concentrated. In 2015, the six largest banking groups made up $83 \%$ of banks' assets and 91\% of lending (ACPR, 2017). All of these banking groups are supervised under the Single Supervisory Mechanism by the European Central Bank. Four out of the major six French banking groups have also been defined as Global Systemically Important Banks (G-SIBs) and are thus subject to higher regulatory requirements.

The French retail banking market is dominated by universal banks. In the last decades, these have also expanded their operations abroad. The upper panel of table 2 lists the summary statistics for the French banks in our sample. As already alluded to above, the distribution of the size of French banks is extremely skewed. On average, loans make up $41 \%$ of all assets and out of these loans about $55 \%$ are vis-à-vis the non-financial sector. Loans to residents largely dominate $(88 \%)$ and the summary statistics also show that the foreign currency fraction of loans to the non-financial sector is larger for non-residents $(22 \%)$ than for residents $(3 \%)$.

Exposures in terms of deposits in the US and the UK constitute our main variables of interest for identifying the channels of transmission. As a fraction of total assets, crossborder deposit exposures are actually quite small and the highest for the UK, representing the fact that French banks are active in the London interbank market.

We restrict our sample to those banks that lend at least $10 \%$ of their assets to the nonfinancial sector and have at least $0.25 \%$ of their total assets in cross-border loans or deposits in either the US or UK. The summary statistics for this restricted sample is also displayed in the upper panel of table 2. The sample restriction changes the mean size of the banks in the sample and raises the part of loans to the non-financial sector. We thus eliminate very small banks and branches of foreign banks resident in France who hardly engage in lending to the non-financial sector. As a consequence, the foreign currency share to both residents and non-residents is higher (9\% and $40 \%$ respectively) and the cross-border exposure to the US and the UK is (by definition) higher for the banks that we retain in our sample for the regressions.

\section{$3.2 \quad$ Italy}

The Italian banking system is less concentrated than the French one: as of end of 2016 there are 14 significant banks supervised directly by the European Central Bank within the Single Supervisory Mechanism; their assets represent about three quarters of total assets of the Italian banking system. Only one of these banking groups is classified as a 
G-SIB. Italian banks tend to have a traditional business model, mostly engaging in lending. Loans represent on average $70 \%$ of assets and they are largely directed to the private non-financial sector, that represents about four fifth of the total (table 2, panel b). The resident component of the loans to the non-financial sector is predominant (98\%). As for the currency breakdown, foreign currency denominated loans to the non-resident non-financial sector represent $10 \%$ of the total while this share is much lower (1\%) for residents. Deposits from the US and the UK, our transmission channel variables on the liability side of Italian banks' balance-sheets, represent respectively less than $1 \%$ and nearly $2 \%$ of total liabilities.

We restrict our sample to banks with foreign affiliates or with cross-border loans larger than $2 \%$ of total assets; these are labeled as international banks and their summary statistics are also displayed in panel b of table 2. Banks in our restricted sample tend to be larger and relatively less exposed to the private non-financial sector, compared to the average Italian bank: the share of loans to the non-financial sector in total loans is $62 \%$. Of course, given the criteria for the sample restriction, their degree of foreign exposure is larger: the share of loans to the non-resident non-financial sector is $7.5 \%$ on average. Also, the foreign currency component of loans to the non-financial sector doubles to $2 \%$ and $22 \%$ respectively for residents and non-residents. As shown by Caccavaio et al. (2015), Italian banks lend cross-border predominantly to Euro area counterparties, other Eastern European countries, the UK and North America. On average, cross-border loans and deposits vis-à-vis the UK are the most relevant component of the non-Euro area exposures (respectively $2 \%$ and $6 \%$ of total assets in the restricted sample), followed by the US (respectively $0.3 \%$ and $0.5 \%$ ).

\subsection{Comparing French and Italian banks' potential to transmit foreign monetary policy shocks}

\section{Dependent variable}

We are interested in the spillovers of foreign monetary policy shocks to the real economy which is why we concentrate on lending to the non-financial sector. In France and Italy, loans to the non-financial resident sector are roughly one order of magnitude larger than in the case of loans to banks or non-bank financial institutions.

Figure 2 compares the level of the dependent variable, loans to the domestic private non-financial sector, over time for both France and Italy, disaggregated into EUR and foreign currency (FC) loans. In France, the continuous expansion of lending to the private non-financial sector is largely driven by real estate loans due to the strong performance of the housing market since 2000. As previously mentioned, foreign currency loans to French residents are more than an order of magnitude lower than EUR-denominated loans. Over 
time, French banks expanded both their FC and EUR lending, but the increase is a bit less pronounced for the former than for the latter.

Figure 2: Dependent variable in levels

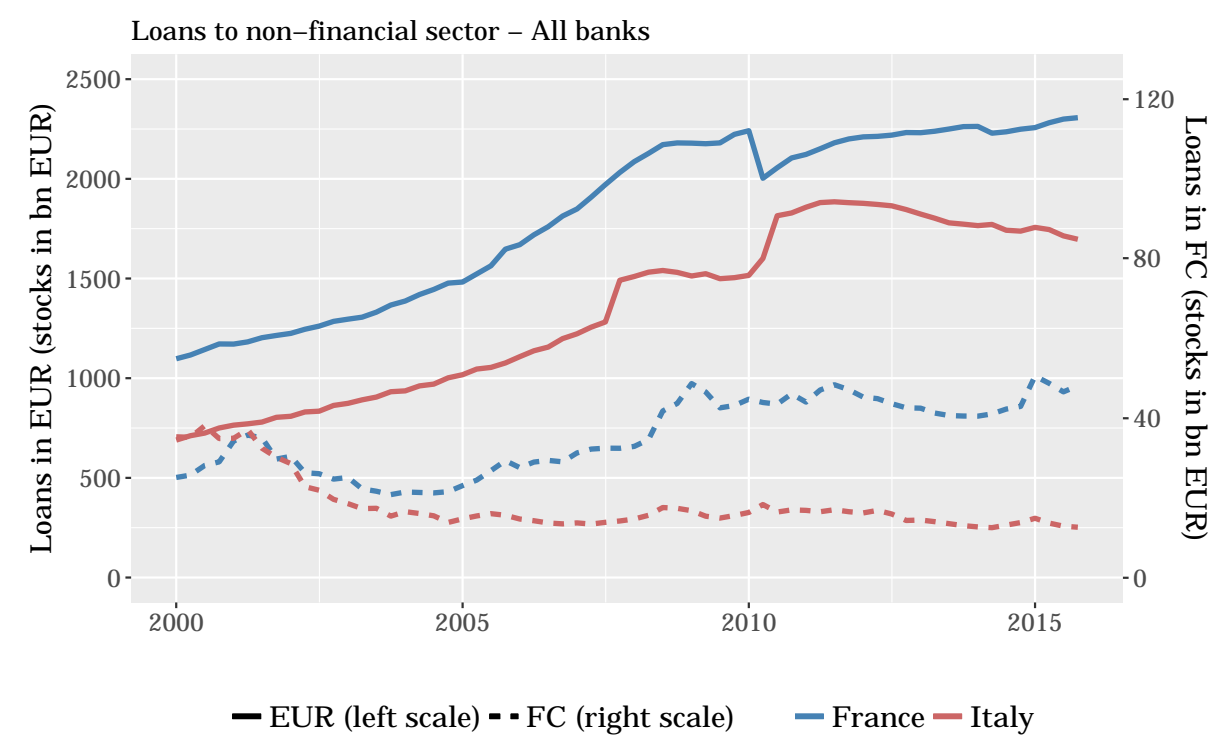

Notes: This figure shows the end-of-quarter outstanding amounts of the loans to the private non-financial sector - broken down by currency, euro (EUR) and foreign currencies (FC) over the period 2000-2015 for the full sample of French and Italian banks. A comprehensive description of the variables can be found in table 7 .

In Italy, we can observe similar differences regarding the order of magnitude between EUR and FC lending. Lending to the private non-financial sector also increased over the time period under consideration; however, this is only the case for EUR lending whereas FC lending continuously decreased over 2000-2015.

\section{Bank lending channel}

Figure 3 shows the evolution of our main transmission channel variables, i.e. deposits placed by residents in the US/UK, over the period 2000-2015 and compares them to loans extended by French and Italian banks to residents in the US/UK. Several features are shared by both French and Italian banks, while there are also important differences. As shown in figure 3, exposures in the US were higher in terms of deposits than in terms of loans until 2011. Thus, both French and Italian banks were relying on the US as a funding source rather than an investment destination. In 2011, US funding to Eurozone banks collapsed due to concerns about these banks' exposure to European sovereigns (Ivashina et al., 2015). In recent years, loans to the US as well as deposits from the US amounted 
to the same levels, thus putting an end to the primary role of the US as a funding market. Another striking similarity is the fact that cross-border deposits and loans denominated in USD - regardless of the counterparty residency, be it in the US or in other countries - largely exceed, respectively, deposits and loans from/to residents in the US alone. This feature is representative of French and Italian banks' activities in the eurodollar market, i.e. USD-denominated loans and deposits vis-à-vis residents outside the US.

Figure 3: Exposures to US and UK

(a) France - US

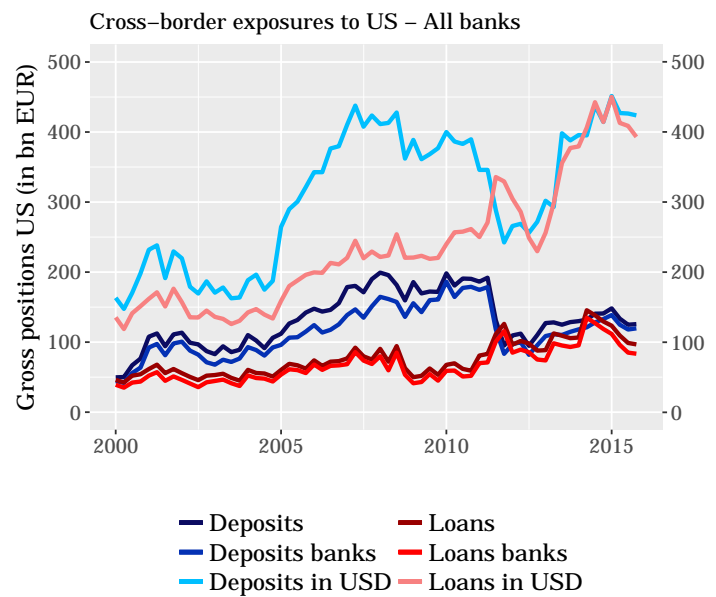

(c) France - UK

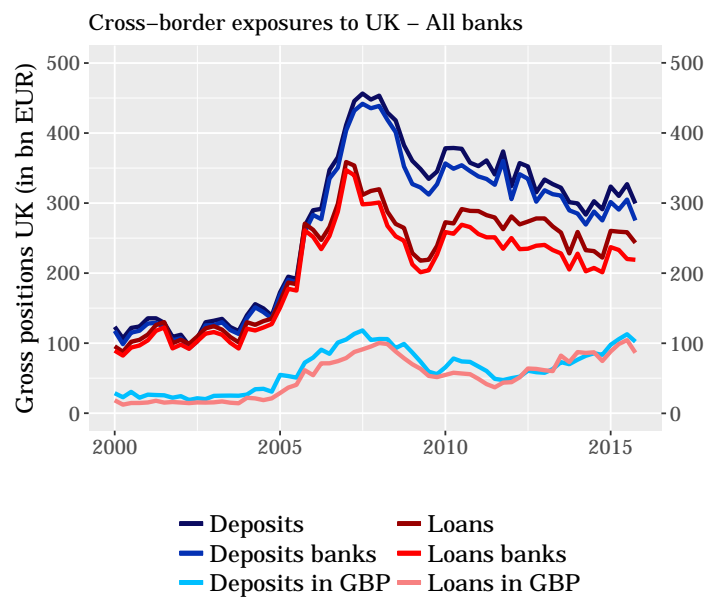

(b) Italy - US

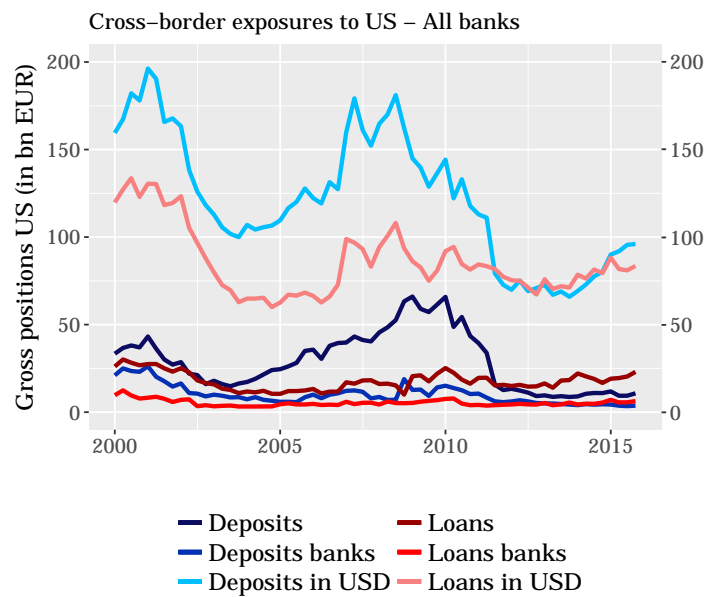

(d) Italy - UK

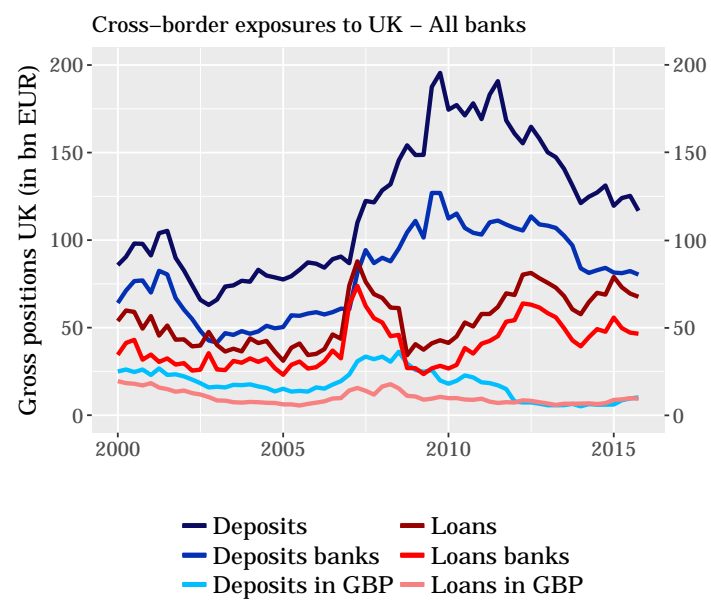

Notes: The figure shows the level of exposure to US (panel a and b) and UK (panel c and d) for the restricted sample of French and Italian banks over the period 2000-2015. The exposures are reported in terms of loans and deposits of the French and Italian banks in the restricted sample. The variables are: the cross-border deposits placed by US (UK) residents, the subset of cross-border deposits placed by US (UK) banks, the cross-border deposits denominated in US dollars (GB pounds), the cross-border loans to US (UK) residents, the subset of cross-border loans to US (UK) banks and the cross-border loans denominated in US dollars (GB pounds). Further details on the restricted sample of banks can be found in the notes of table 2. A comprehensive description of the variables can be found in table 7 . 
One remarkable difference between French and Italian banks' exposures to the US is that cross-border deposits from US residents at French banks are largely coming from banks whereas this is not the case for Italian banks. As explained in Shin (2012), French banks' affiliates in the US raised USD funding and channeled these funds to France. The summary statistics as well as the large discrepancy between funding and loans vis-à-vis US banks and in USD as depicted in figure 3 support this line of argument.

Italian banks, on the contrary, were making less use of their affiliate network in the US to raise USD funding. As Italian banks' international expansion began in the early 2000s, it often followed the foreign delocalization patterns of its pre-existing clientele, mostly in Central and Eastern Europe. More recently, the outward expansion of branches and subsidiaries was less related to the original presence of borrowers; still, the large bulk of foreign presence of Italian banks is concentrated in the Euro area, which means that a significant share of the transactions for their affiliates' network is denominated in EUR in both assets and liabilities. Furthermore, relative to French banks, Italian ones have traditionally been less active in transactions with US money market funds and US Treasury repos, which makes them less exposed to USD funding. All in all, this has translated into a lower reliance of Italian banks on foreign sources of funding coming from abroad. Most importantly however, we remark a difference in magnitudes between French and Italian banks' exposures vis-à-vis the US. In general, these exposures are twice as high for France than for Italy (and in relative terms, this difference is even more pronounced: for the average Italian bank, US deposits as a fraction of total assets represent less than one forth of the corresponding fraction in the case of French banks, see table 2).

While USD exposures are relatively large, exposures in the US are only about half (or even less) the size of the exposures to the UK. Actually, the UK represents the primary market for cross-border loans and deposits due to the role of the UK as a large banking hub. However, contrary to the upper panel of figure 3, cross-border loans and deposits in GBP (to/from UK residents, but also to/from other non-residents) are small compared to overall loans and deposits to/from UK residents. Thus, while the UK plays an important role as a banking hub, transactions with the UK are largely made in other currencies than GBP (notably euro and eurodollar). As in the case of the US, we notice the higher magnitudes for French banks' exposures to the UK and the fact that most of the cross-border loans and deposits are vis-à-vis banks whereas this is less the case for Italian banks.

In the regression framework, we use the data on cross-border deposits as depicted in the blue lines in figure 3 for the variable Channel $c_{b, t-k-1}^{c t r y}$. For the regressions, we scale these deposits by overall liabilities to calculate the dependence on US (UK) funding for each bank. The mean of these funding dependency ratios are displayed in figure 4 , both 
for French and Italian banks. In line with the summary statistics and figure 3, these ratios are higher for French than for Italian banks. Once again, we notice the stark difference between the US and the UK regarding the currency composition of cross-border deposits.

Figure 4: Bank lending channel variables - Mean over 2000Q1-2015Q4

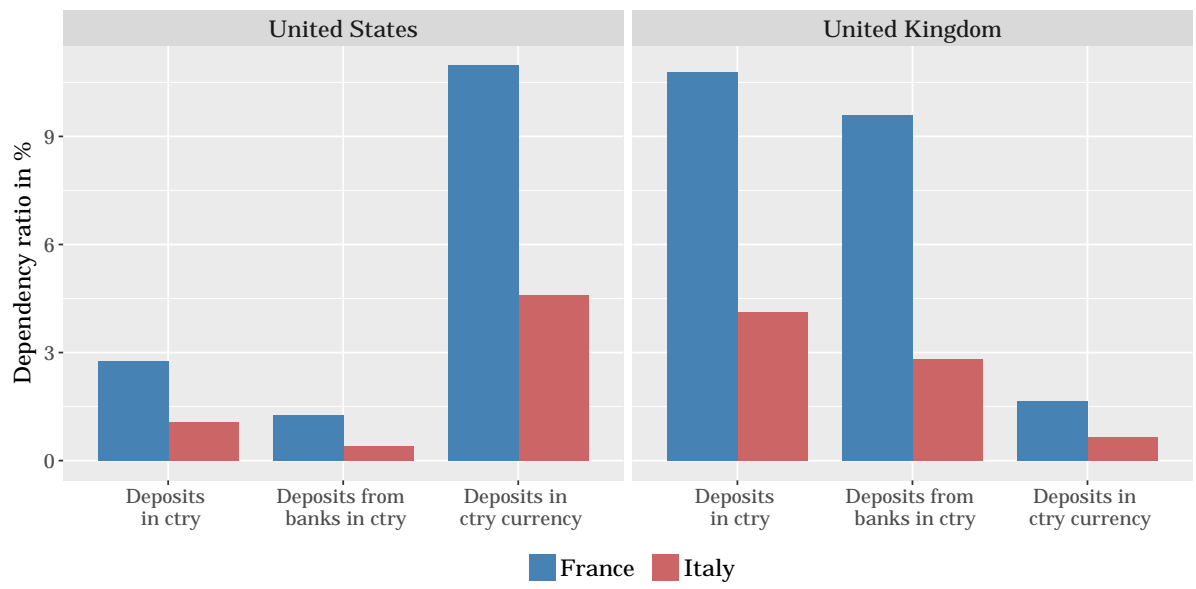

Notes: The figure shows the average shares of deposits placed by US (UK) residents for the restricted sample of French and Italian banks over the period 2000-2015. The shares are calculated as the percentage ratio of the sum of cross-border deposits over time from US (UK) residents over total liabilities. The computation is reported also for the subset of cross-border deposits placed by US (UK) banks and for all cross-border deposits denominated in US dollars (GB pounds). A comprehensive description of the variables can be found in table 7 .

\section{Results}

\section{Baseline results}

Tables $3-5$ summarize the results where we investigate the existence of an international bank lending channel. Table 3 looks at the reaction of loans to the non-financial sector in all currencies. For both France and Italy, we find a significant and negative effect when the shock is identified using reliance on US bank funding as a channel variable. For the case of France, we also note that a UK monetary policy tightening is associated with a decrease in lending when using overall GBP deposits to identify the shock.

In the case of Italian banks, the effect is larger for the interbank component of deposits from the US (column 2). The story is consistent with the historical episodes of funding disruptions that affected domestic lending. During the 2008-09 financial crisis and even more so during the European sovereign debt crisis of the second half of 2011, Italian banks experienced a massive funding dry-up that was largely driven by withdrawal of US money market funds and the drop in repos with central counterparties. The impact of this funding 
shock on credit supply is well documented (Bofondi et al., 2017; Carpinelli and Crosignani, 2017) and, although not stemming from monetary policy, it testifies the potential disruptions in terms of deleveraging that a high reliance on volatile sources of funding can generate. Furthermore, separate regressions splitting the left hand side variable by sector of counterparty between firms and households show that adjustment occurs only in lending to the former.

\section{Table 3: Bank lending channel: effect on resident lending} (all currencies)

\begin{tabular}{|c|c|c|c|}
\hline \multicolumn{4}{|c|}{ France } \\
\hline & $\begin{array}{c}(1) \\
\text { Ctry } \\
\text { deposits }\end{array}$ & $\begin{array}{c}(2) \\
\text { Ctry deposits } \\
\text { to banks }\end{array}$ & $\begin{array}{c}(3) \\
\text { Deposits in } \\
\text { ctry currency }\end{array}$ \\
\hline Channel $\times$ MP US & $\begin{array}{l}-0.085 \\
{[0.450]}\end{array}$ & $\begin{array}{c}-0.628^{* *} \\
{[0.044]}\end{array}$ & $\begin{array}{c}-0.043 \\
{[0.556]}\end{array}$ \\
\hline Channel $\times$ MP UK & $\begin{array}{c}0.021 \\
{[0.375]}\end{array}$ & $\begin{array}{c}0.031 \\
{[0.205]}\end{array}$ & $\begin{array}{l}-0.357^{* *} \\
{[0.029]}\end{array}$ \\
\hline Channel US & $\begin{array}{c}0.007 \\
{[0.960]}\end{array}$ & $\begin{array}{l}-0.165 \\
{[0.567]}\end{array}$ & $\begin{array}{l}-0.085 \\
{[0.237]}\end{array}$ \\
\hline Channel UK & $\begin{array}{c}0.047 \\
{[0.181]}\end{array}$ & $\begin{array}{c}0.042 \\
{[0.179]}\end{array}$ & $\begin{array}{c}0.162 \\
{[0.487]}\end{array}$ \\
\hline Observations & 4804 & 4806 & 4809 \\
\hline$R^{2}$ & 0.12 & 0.13 & 0.12 \\
\hline Adjusted $R^{2}$ & 0.06 & 0.07 & 0.07 \\
\hline Number of banks & 230 & 230 & 230 \\
\hline \multicolumn{4}{|c|}{ Italy } \\
\hline & $\begin{array}{c}(1) \\
\text { Ctry } \\
\text { deposits }\end{array}$ & $\begin{array}{c}(2) \\
\text { Ctry deposits } \\
\text { to banks }\end{array}$ & $\begin{array}{c}(3) \\
\text { Deposits in } \\
\text { ctry currency }\end{array}$ \\
\hline Channel $\times$ MP US & $\begin{array}{c}-1.172 \\
{[0.103]}\end{array}$ & $\begin{array}{c}-1.851^{*} \\
{[0.067]}\end{array}$ & $\begin{array}{c}-0.265^{*} \\
{[0.080]}\end{array}$ \\
\hline Channel $\times$ MP UK & $\begin{array}{c}0.042 \\
{[0.451]}\end{array}$ & $\begin{array}{l}-0.187 \\
{[0.311]}\end{array}$ & $\begin{array}{c}1.192 \\
{[0.137]}\end{array}$ \\
\hline Channel US & $\begin{array}{l}-0.418^{* *} \\
{[0.012]}\end{array}$ & $\begin{array}{l}-0.583^{* *} \\
{[0.011]}\end{array}$ & $\begin{array}{l}-0.234^{* *} \\
{[0.038]}\end{array}$ \\
\hline Channel UK & $\begin{array}{c}-0.033 \\
{[0.285]}\end{array}$ & $\begin{array}{l}-0.328 \\
{[0.304]}\end{array}$ & $\begin{array}{c}0.521 \\
{[0.265]}\end{array}$ \\
\hline Observations & 3316 & 3316 & 3316 \\
\hline$R^{2}$ & 0.23 & 0.23 & 0.23 \\
\hline Adjusted $R^{2}$ & 0.19 & 0.19 & 0.18 \\
\hline Number of banks & 94 & 94 & 94 \\
\hline
\end{tabular}

Notes: This table reports the regression results for the empirical specification in equation (1). The numbers represent the sum of coefficients on the monetary policy variables summed over the three lags and the contemporaneous variables. All regressions are OLS regressions; standard errors are clustered at bank level. $\mathrm{P}$-values are reported in brackets. The transmission channel variable is reported in the column headers.

Both Italian and French banks rely on a stable supply of domestic retail funding in EUR. However, regarding the overall composition of their resident lending, French banks, in contrast to Italian banks, extend a larger fraction of their loans to the non-financial 
resident sector in foreign currency (see table 2). The response to foreign monetary policy changes might therefore differ between French and Italian banks simply because their asset portfolios are differently structured and thus provide different room for adjustment.

We therefore disaggregate total loans to the non-financial sector into the loans that are respectively denominated in EUR and in FC. Table 4 reports these results which show a remarkable difference between French and Italian banks. In France, there are significant and negative effects for all the channel variables in the case of US monetary policy tightening for the case of foreign-currency lending. ${ }^{5}$ In Italy, on the contrary, it is EUR lending and not FC lending that contracts in response to a monetary policy tightening in the US. In Italy, the share of foreign currency loans to residents represents a very small share of overall loans to residents and might therefore not react to foreign monetary policy changes.

For the case of UK monetary policy tightening, we actually observe a positive coefficient when the shock is identified using UK and UK bank deposits for the case of Italy and GBP deposits for the case of France. This positive coefficient could on the one hand imply that GBP loans (which are a small subset of FC loans) expand in reaction to a monetary policy tightening due to the existence of a balance sheet channel (Bernanke and Gertler, 1995) where the creditworthiness of borrowers declines and banks thus shift their lending to resident borrowers. On the other hand, lending in FC could expand in reaction to UK monetary policy changes because other components of FC loans (such as USD loans) expand, thus suggesting substitution effects among different currencies. In order to explain these differences in more detail, we investigate whether the reaction of FC lending is indeed driven by lending in the currency of the respective monetary policy change. We expect USD loans to contract in response to US monetary policy tightening and GBP loans in response to UK monetary policy tightening. Table 5 shows the respective results. ${ }^{6}$

\footnotetext{
${ }^{5}$ We want to point out that these results are not robust to the exclusion of foreign banks in France as our restricted sample is based on banks that have significant cross-border exposure to the UK and the US and thus also higher foreign currency lending in France (see section 3.1). Excluding foreign banks leads to a substantial loss of observations and thus eliminates banks from our sample that are essential for the transmission of foreign monetary policy changes.

${ }^{6}$ For the French data, we are not able to disaggregate the foreign-currency loans in the non-financial sector by currency denomination. However, we have this information for the non-bank sector, combining thus loans to the non-financial as well as as the non-bank financial sector.
} 
Table 4: Bank lending channel: effect on resident lending, by EUR/FC

\begin{tabular}{|c|c|c|c|c|c|c|}
\hline \multicolumn{7}{|c|}{ France } \\
\hline & \multicolumn{3}{|c|}{ Loans to residents in EUR } & \multicolumn{3}{|c|}{ Loans to residents in $\mathrm{FC}$} \\
\hline & $\begin{array}{c}(1) \\
\text { Ctry } \\
\text { deposits }\end{array}$ & $\begin{array}{c}(2) \\
\text { Ctry deposits } \\
\text { to banks }\end{array}$ & $\begin{array}{c}(3) \\
\text { Deposits in } \\
\text { ctry currency }\end{array}$ & $\begin{array}{c}(4) \\
\text { Ctry } \\
\text { deposits }\end{array}$ & $\begin{array}{c}(5) \\
\text { Ctry deposits } \\
\text { to banks }\end{array}$ & $\begin{array}{c}(6) \\
\text { Deposits in } \\
\text { ctry currency }\end{array}$ \\
\hline Channel $\times$ MP US & $\begin{array}{c}0.048 \\
{[0.433]}\end{array}$ & $\begin{array}{c}0.058 \\
{[0.827]}\end{array}$ & $\begin{array}{c}0.011 \\
{[0.856]}\end{array}$ & $\begin{array}{c}-0.733^{* *} \\
{[0.021]}\end{array}$ & $\begin{array}{l}-1.155^{* * *} \\
{[0.003]}\end{array}$ & $\begin{array}{c}-0.210^{*} \\
{[0.075]}\end{array}$ \\
\hline Channel $\times$ MP UK & $\begin{array}{c}0.021 \\
{[0.385]}\end{array}$ & $\begin{array}{c}0.023 \\
{[0.362]}\end{array}$ & $\begin{array}{l}-0.222 \\
{[0.136]}\end{array}$ & $\begin{array}{c}0.060^{*} \\
{[0.082]}\end{array}$ & $\begin{array}{l}0.082^{* * *} \\
{[0.010]}\end{array}$ & $\begin{array}{c}0.126 \\
{[0.586]}\end{array}$ \\
\hline Channel US & $\begin{array}{l}0.159^{* *} \\
{[0.042]}\end{array}$ & $\begin{array}{l}0.316^{* *} \\
{[0.035]}\end{array}$ & $\begin{array}{c}-0.047 \\
{[0.369]}\end{array}$ & $\begin{array}{l}-0.166 \\
{[0.328]}\end{array}$ & $\begin{array}{l}-0.173 \\
{[0.501]}\end{array}$ & $\begin{array}{l}-0.225^{* *} \\
{[0.010]}\end{array}$ \\
\hline Channel UK & $\begin{array}{c}0.034 \\
{[0.349]} \\
\end{array}$ & $\begin{array}{c}0.023 \\
{[0.487]}\end{array}$ & $\begin{array}{c}0.206 \\
{[0.324]}\end{array}$ & $\begin{array}{c}0.033 \\
{[0.612]} \\
\end{array}$ & $\begin{array}{c}0.073 \\
{[0.201]} \\
\end{array}$ & $\begin{array}{c}0.293 \\
{[0.170]}\end{array}$ \\
\hline Observations & 4783 & 4785 & 4788 & 3156 & 3156 & 3159 \\
\hline$R^{2}$ & 0.11 & 0.11 & 0.11 & 0.10 & 0.10 & 0.10 \\
\hline Adjusted $R^{2}$ & 0.05 & 0.05 & 0.05 & 0.03 & 0.03 & 0.03 \\
\hline Number of banks & 230 & 230 & 230 & 150 & 150 & 150 \\
\hline \multicolumn{7}{|c|}{ Italy } \\
\hline & \multicolumn{3}{|c|}{ Loans to residents in EUR } & \multicolumn{3}{|c|}{ Loans to residents in FC } \\
\hline & $\begin{array}{c}(1) \\
\text { Ctry } \\
\text { deposits }\end{array}$ & $\begin{array}{l}(2) \\
\text { Ctry deposits } \\
\text { to banks }\end{array}$ & $\begin{array}{c}(3) \\
\text { Deposits in } \\
\text { ctry currency }\end{array}$ & $\begin{array}{c}(4) \\
\text { Ctry } \\
\text { deposits }\end{array}$ & $\begin{array}{l}(5) \\
\text { Ctry deposits } \\
\text { to banks }\end{array}$ & $\begin{array}{c}(6) \\
\text { Deposits in } \\
\text { ctry currency }\end{array}$ \\
\hline Channel $\times$ MP US & $\begin{array}{c}-1.231^{*} \\
{[0.098]}\end{array}$ & $\begin{array}{c}-1.955^{*} \\
{[0.065]}\end{array}$ & $\begin{array}{l}-0.320^{* *} \\
{[0.039]}\end{array}$ & $\begin{array}{c}-0.037 \\
{[0.972]}\end{array}$ & $\begin{array}{c}4.029 * \\
{[0.056]}\end{array}$ & $\begin{array}{c}0.402 \\
{[0.247]}\end{array}$ \\
\hline Channel $\times$ MP UK & $\begin{array}{c}0.050 \\
{[0.302]}\end{array}$ & $\begin{array}{l}-0.123 \\
{[0.404]}\end{array}$ & $\begin{array}{l}1.620^{* *} \\
{[0.032]}\end{array}$ & $\begin{array}{l}-0.193 \\
{[0.173]}\end{array}$ & $\begin{array}{l}-0.266 \\
{[0.231]}\end{array}$ & $\begin{array}{l}-2.205 \\
{[0.311]}\end{array}$ \\
\hline Channel US & $\begin{array}{l}-0.430^{* *} \\
{[0.014]}\end{array}$ & $\begin{array}{l}-0.626^{* *} \\
{[0.014]}\end{array}$ & $\begin{array}{l}-0.248^{* *} \\
{[0.030]}\end{array}$ & $\begin{array}{l}0.235 \\
{[0.711]}\end{array}$ & $\begin{array}{c}2.161 \\
{[0.102]}\end{array}$ & $\begin{array}{c}0.296 \\
{[0.282]}\end{array}$ \\
\hline Channel UK & $\begin{array}{l}-0.057^{*} \\
{[0.063]}\end{array}$ & $\begin{array}{l}-0.247 \\
{[0.341]}\end{array}$ & $\begin{array}{l}0.857^{* *} \\
{[0.029]}\end{array}$ & $\begin{array}{l}-0.116 \\
{[0.563]}\end{array}$ & $\begin{array}{c}0.253 \\
{[0.222]}\end{array}$ & $\begin{array}{l}-1.380 \\
{[0.248]}\end{array}$ \\
\hline Observations & 3316 & 3316 & 3316 & 2151 & 2151 & 2151 \\
\hline$R^{2}$ & 0.23 & 0.23 & 0.23 & 0.21 & 0.22 & 0.21 \\
\hline Adjusted $R^{2}$ & 0.19 & 0.19 & 0.19 & 0.16 & 0.16 & 0.16 \\
\hline Number of banks & 94 & 94 & 94 & 65 & 65 & 65 \\
\hline
\end{tabular}

Notes: This table reports the regression results for the empirical specification in equation (1). The numbers represent the sum of coefficients on the monetary policy variables summed over the three lags and the contemporaneous variables. All regressions are OLS regressions; standard errors are clustered at bank level. P-values are reported in brackets. The transmission channel variable is reported in the column headers.

As overall FC lending did not react to US or UK monetary policy changes in the case of Italian results, the non-significant responses for Italy in table 5 are in line with table 4 . For France, we do indeed find a significant and negative effect on USD lending in the case of US monetary policy shocks (identified via dependence on USD funding, see column 3), but this is not the case for UK monetary policy shocks: none of the coefficients are significant in columns $4-6$ of table 5 . 
Table 5: Bank lending channel: effect on resident lending, by USD/GBP

\begin{tabular}{|c|c|c|c|c|c|c|}
\hline \multicolumn{7}{|c|}{ France } \\
\hline & \multicolumn{3}{|c|}{ Loans to residents in USD } & \multicolumn{3}{|c|}{ Loans to residents in GBP } \\
\hline & $\begin{array}{c}(1) \\
\text { Ctry } \\
\text { deposits }\end{array}$ & $\begin{array}{l}(2) \\
\text { Ctry deposits } \\
\text { to banks }\end{array}$ & $\begin{array}{c}(3) \\
\text { Deposits in } \\
\text { ctry currency }\end{array}$ & $\begin{array}{c}(4) \\
\text { Ctry } \\
\text { deposits }\end{array}$ & $\begin{array}{c}(5) \\
\text { Ctry deposits } \\
\text { to banks }\end{array}$ & $\begin{array}{c}(6) \\
\text { Deposits in } \\
\text { ctry currency }\end{array}$ \\
\hline Channel $\times$ MP US & $\begin{array}{l}-0.753 \\
{[0.121]}\end{array}$ & $\begin{array}{l}-0.981 \\
{[0.134]}\end{array}$ & $\begin{array}{l}-0.352^{* *} \\
{[0.012]}\end{array}$ & $\begin{array}{c}0.549 \\
{[0.574]}\end{array}$ & $\begin{array}{c}0.750 \\
0.371]\end{array}$ & $\begin{array}{c}0.385^{*} \\
{[0.088]}\end{array}$ \\
\hline Channel $\times$ MP UK & $\begin{array}{c}0.029 \\
{[0.492]}\end{array}$ & $\begin{array}{l}0.059 \\
{[0.175]}\end{array}$ & $\begin{array}{l}-0.312 \\
{[0.377]}\end{array}$ & -0.047 & $\begin{array}{c}-0.073 \\
{[0.333]}\end{array}$ & $\begin{array}{l}-0.684 \\
{[0.138]}\end{array}$ \\
\hline Channel US & $\begin{array}{l}-0.197 \\
{[0.443]}\end{array}$ & $\begin{array}{c}0.036 \\
{[0.912]}\end{array}$ & $\begin{array}{l}-0.158 \\
{[0.346]}\end{array}$ & $\begin{array}{l}0.555 \\
{[0.403]}\end{array}$ & $\begin{array}{c}0.793 \\
{[0.393]}\end{array}$ & $\begin{array}{l}-0.337 \\
{[0.225]}\end{array}$ \\
\hline Channel UK & $\begin{array}{c}0.076 \\
{[0.435]}\end{array}$ & $\begin{array}{c}0.098 \\
{[0.170]}\end{array}$ & $\begin{array}{l}-0.493^{*} \\
{[0.079]}\end{array}$ & $\begin{array}{c}0.177 \\
{[0.146]}\end{array}$ & $\begin{array}{l}0.196^{* * *} \\
{[0.002]}\end{array}$ & $\begin{array}{c}0.188 \\
{[0.861]}\end{array}$ \\
\hline Observations & 2051 & 2053 & 2055 & 1031 & 1031 & 1032 \\
\hline$R^{2}$ & 0.12 & 0.12 & 0.12 & 0.12 & 0.12 & 0.12 \\
\hline Adjusted $R^{2}$ & 0.02 & 0.02 & 0.03 & -0.03 & -0.03 & -0.02 \\
\hline Number of banks & 125 & 125 & 125 & 83 & 83 & 83 \\
\hline \multicolumn{7}{|c|}{ Italy } \\
\hline & \multicolumn{3}{|c|}{ Loans to residents in USD } & \multicolumn{3}{|c|}{ Loans to residents in GBP } \\
\hline & $\begin{array}{c}(1) \\
\text { Ctry } \\
\text { deposits }\end{array}$ & $\begin{array}{c}(2) \\
\text { Ctry deposits } \\
\text { to banks }\end{array}$ & $\begin{array}{c}(3) \\
\text { Deposits in } \\
\text { ctry currency }\end{array}$ & $\begin{array}{c}(4) \\
\text { Ctry } \\
\text { deposits }\end{array}$ & $\begin{array}{c}(5) \\
\text { Ctry deposits } \\
\text { to banks }\end{array}$ & $\begin{array}{c}(6) \\
\text { Deposits in } \\
\text { ctry currency }\end{array}$ \\
\hline Channel $\times$ MP US & $\begin{array}{c}-0.374 \\
{[0.731]}\end{array}$ & $\begin{array}{c}3.021 \\
{[0.199]}\end{array}$ & $\begin{array}{c}0.094 \\
{[0.878]}\end{array}$ & $\begin{array}{c}1.292 \\
{[0.707]}\end{array}$ & $\begin{array}{c}6.183 \\
{[0.233]}\end{array}$ & $\begin{array}{c}-0.331 \\
{[0.713]}\end{array}$ \\
\hline Channel $\times$ MP UK & $\begin{array}{c}-0.182 \\
{[0.277]}\end{array}$ & $\begin{array}{l}-0.096 \\
{[0.732]}\end{array}$ & $\begin{array}{l}-0.876 \\
{[0.780]}\end{array}$ & $\begin{array}{l}-0.113 \\
{[0.851]}\end{array}$ & $\begin{array}{c}-0.693 \\
{[0.429]}\end{array}$ & $\begin{array}{c}6.164 \\
{[0.206]}\end{array}$ \\
\hline Channel US & $\begin{array}{c}0.443 \\
{[0.560]}\end{array}$ & $\begin{array}{c}2.703 \\
{[0.106]}\end{array}$ & $\begin{array}{c}-0.036 \\
{[0.912]}\end{array}$ & $\begin{array}{c}2.594 \\
{[0.204]}\end{array}$ & $\begin{array}{c}4.460 \\
{[0.390]}\end{array}$ & $\begin{array}{c}0.074 \\
{[0.934]}\end{array}$ \\
\hline Channel UK & $\begin{array}{l}-0.129 \\
{[0.624]}\end{array}$ & $\begin{array}{l}0.471^{* *} \\
{[0.031]}\end{array}$ & $\begin{array}{c}0.637 \\
{[0.532]}\end{array}$ & $\begin{array}{l}-0.551 \\
{[0.330]}\end{array}$ & $\begin{array}{c}0.948 \\
{[0.261]}\end{array}$ & $\begin{array}{c}2.723 \\
{[0.339]}\end{array}$ \\
\hline Observations & 1694 & 1694 & 1694 & 698 & 698 & 698 \\
\hline$R^{2}$ & 0.29 & 0.30 & 0.30 & 0.22 & 0.23 & 0.21 \\
\hline Adjusted $R^{2}$ & 0.24 & 0.24 & 0.24 & 0.10 & 0.10 & 0.09 \\
\hline Number of banks & 52 & 52 & 52 & 28 & 28 & 28 \\
\hline
\end{tabular}

Notes: This table reports the regression results for the empirical specification in equation (1). The numbers represent the sum of coefficients on the monetary policy variables summed over the three lags and the contemporaneous variables. All regressions are OLS regressions; standard errors are clustered at bank level. P-values are reported in brackets. The transmission channel variable is reported in the column headers.

Several reasons could explain this pattern. The funding exposures to the UK are about twice as high as to the US. However, a large share of these exposures is not in GBP, but in other currencies such as eurodollars or EUR. Hedging costs increase substantially only when cross-currency flows are actually quite large. The exposures to GBP funding and the capital flows in response to monetary policy changes might therefore not be large enough to move the forward premium (Bräuning and Ivashina, 2017; Avdjiev et al., 2016). As a result of the small funding exposures in GBP, UK monetary policy changes might not lead to sufficiently large capital flows (as in the case of USD funding), thus isolating French and Italian banks from UK monetary policy shocks. 
When monetary policy tightens in the US, French banks decrease their FC lending (which is presumably largely composed of USD lending). This finding is thus in line with the idea that tensions in currency swap markets can lead to a contraction in foreign currency lending in response to foreign monetary policy shocks. Since the Great Financial Crisis, there have been persistent and large deviations from covered interest parity (CIP) as demonstrated for example by Du et al. (2017) or Borio et al. (2016). Thus, strains in cross-currency markets arise which prevent funding in different currencies to be perfect substitutes. We will investigate this issue further below.

What are the effects in terms of economic significance? To answer this, we look at the effect of a $1 \%$ monetary tightening on domestic lending. For the case of France, a bank with a dependence on US funding of $2.92 \%$ (the mean in the restricted sample) will contract FC lending by $2.1 \%(0.0292 \times-0.733)$. The same magnitude is observed in the case of dependence on USD funding, where the average French bank in the restricted sample has a USD funding dependence of $10.7 \%$; as a consequence, lending contracts by $2.2 \%(0.107 \times$ -0.21). This latter effect is concentrated in USD lending with a reduction by $3.8 \%(0.107$ $\times-0.352)$. For Italian banks, a $1 \%$ monetary policy tightening leads to a contraction of EUR lending by $0.3 \%(0.0026 \times-1.231)$ and by $0.5 \%(0.0157 \times-0.32)$ for a bank with the average dependence on US funding and USD funding, respectively. ${ }^{7}$ When translating the impact on FC loans, for France, and EUR loans, for Italy, into an aggregate impact on total credit supply, the effects in the two countries are broadly comparable and all range between $0.2 \%$ and $0.5 \%$. While the magnitudes for FC lending for French banks are an order of magnitude higher than for the case of EUR lending by Italian banks, the overall loan volume in FC for the French sample is only around $9 \%$ of total loans, thus leading to an overall contraction of $0.2 \%(2.1 \% \times 9 \%)$ which is comparable to the overall contraction of EUR lending of Italian banks.

In the case of Italian banks, we observe that it is rather EUR lending that contracts (see table 4). Compared to France, Italian banks do not rely to a large extent on their affiliate network in the US to channel funds from US wholesale funding markets to their headquarters. Figure 3 shows that deposits from US residents are not only smaller than for French banks; they are also coming mainly from non-banks. French banks' deposits in the US largely come from the banking sector, of which affiliates of French banks resident in the US make up a large part. Thus, the type of funding French and Italian banks are receiving from the US might be inherently different and therefore the funding shock affects EUR lending of Italian banks, but not French banks which rely on a very stable and strong

\footnotetext{
${ }^{7}$ For the Italian sample the mean values of USD and US funding dependence are calculated on the banktime observations that are actually used in the regression, and thus differ from the ones reported in Table 2. For the French sample, these are almost identical.
} 
retail deposit market (thus having abundant EUR funding). Nevertheless, one should note that when repeating the analysis on different subsets of Italian banks, we find that for large diversified domestic banks and subsidiaries of foreign banks operating in Italy, that tend to be of large size, Italian banks also decrease their lending in foreign currency. ${ }^{8}$

\section{CIP deviations}

Above, we argued that the significant negative effect of a US monetary policy shock affects foreign currency lending, and in particular USD lending, due to tensions in currency swap markets. These tensions result in higher funding costs which is why banks cut back on their loan supply in foreign currency (USD). In this section, we want to look at this issue more closely by including an indicator of tensions in currency swap markets in our analytical framework to better understand the differential impact of foreign monetary policy shocks on lending in domestic and foreign currency.

As is well documented by now (Ivashina et al., 2015; Borio et al., 2016; Du et al., 2017; Avdjiev et al., 2016), large and persistent deviations from covered interest parity (CIP) have been recorded since the Great Financial Crisis. These deviations have been historically rare, but have repeatedly appeared in international currency markets since 2008-2009.

CIP states that the interest rate differential between two currencies is equal to the difference in the spot and forward exchange rates. Investing one foreign currency unit today will yield $\left(1+i_{t, t+n}^{F C}\right)^{n}$ in $n$ years in foreign currency. In an arbitrage-free world, these proceeds should equal the amount earned when swapping one unit of foreign currency in $s_{t}$ units of EUR, earning interest and therefore receiving $s_{t}\left(1+i_{t, t+n}^{E U R}\right)^{n}$. The corresponding forward contract would convert this amount back into foreign currency: $s_{t}\left(1+i_{t, t+n}^{E U R}\right)^{n} / f_{t, t+n}$. Thus, we follow Du et al. (2017) and define the CIP deviation as

$$
d_{t, t+n}^{F C}=i_{t, t+n}^{F C}-i_{t, t+n}^{E U R}+\frac{1}{n}\left(f_{t, t+n}-s_{t}\right)
$$

where $i_{t, t+n}^{F C}$ is the 3 months Libor rate, based on respectively $F C=U S D$ or $F C=G B P$ and $i_{t, t+n}^{E U R}$ is the 3 months Libor rate, based on the EUR. $n$ is in years and thus takes the value of $1 / 4$ for the case of 3 months Libor and forward rates. The forward rate $f_{t, t+n}$ and the spot rate $s_{t}$ are in terms of EUR per foreign currency and are expressed in logs.

Figure 5 plots the computed deviations from CIP. Before 2008-2009, their respective values were fluctuating around zero, but large (negative) deviations appeared during the Great Financial Crisis. These deviations have been associated with times of doubts about banks'

\footnotetext{
${ }^{8}$ Please also note that we ran all our regressions on subsamples before the financial crisis (2000-2007) and after (2010-2015). Overall, results are broadly symmetric in the two subsamples and are available from the authors upon request.
} 
creditworthiness and high counterparty risk in international interbank markets, making the funding via currency swaps ultimately more costly.

Figure 5: CIP deviations

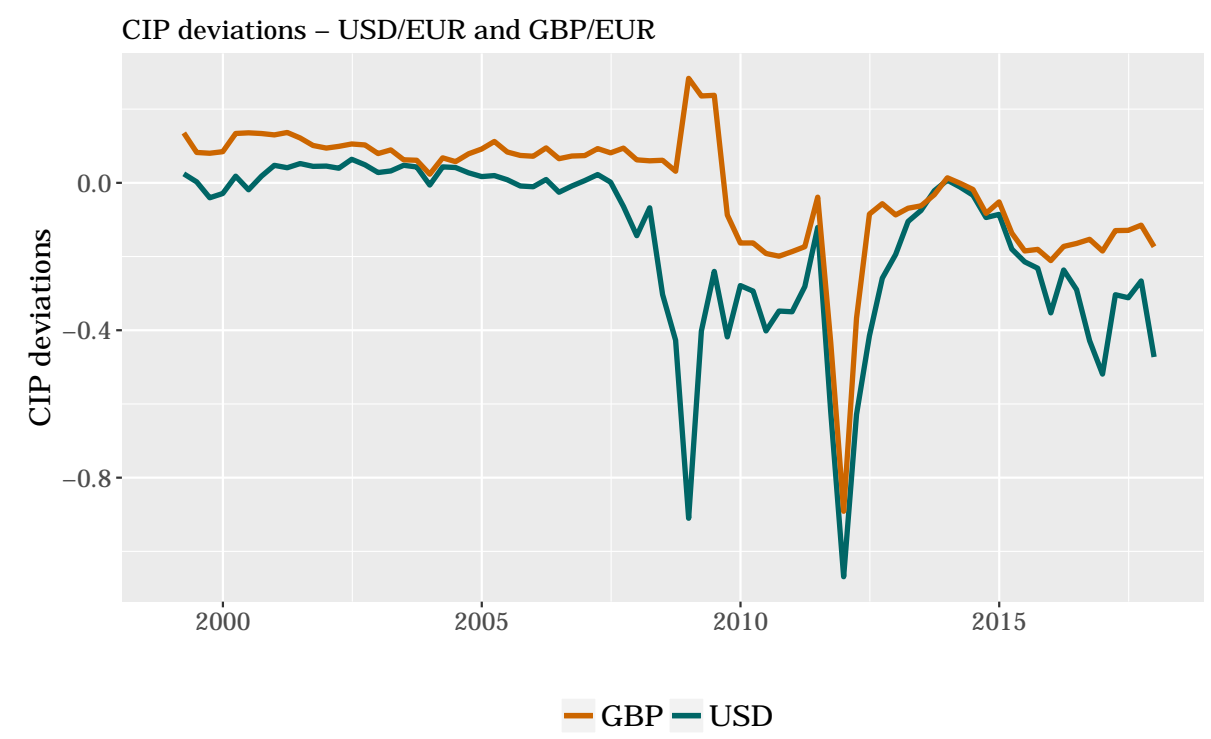

Notes: CIP deviations calculated as described in the text using daily data. The figure plots the average quarterly value.

We then run the following regression set-up where we add the interaction of the bankspecific monetary policy change $\left(\Delta M P_{t-k}^{c t r y} \cdot\right.$ Channel $\left._{b, t-k-1}^{c t r y}\right)$ with an indicator of CIP deviation as well as the interaction of CIP and the channel variable.

$$
\begin{aligned}
\Delta Y_{b, t} & =\alpha_{0}+\sum_{k=0}^{K}\left(\sum_{c t r y} \alpha_{1, k}^{c t r y} \cdot \Delta M P_{t-k}^{c t r y} \cdot \text { Channel }_{b, t-k-1}^{c t r y}\right) \\
& +\sum_{k=0}^{K}\left(\sum_{c t r y} \alpha_{1, k}^{c t r y} \cdot \Delta M P_{t-k}^{c t r y} \cdot C I P_{t-k}^{c t r y} \cdot \text { Channel }_{b, t-k-1}^{c t r y}\right) \\
& +\sum_{k=0}^{K}\left(\sum_{c t r y} \alpha_{1, k}^{c t r y} \cdot C I P_{t-k}^{c t r y} \cdot \text { Channel }_{b, t-k-1}^{c t r y}\right) \\
& +\sum_{c t r y} \alpha_{2}^{c t r y} \text { Channel }{ }_{b, t-k-1}^{c t r y}+\alpha_{3}^{\top} X_{b, t-1}+f_{b}+\eta_{t}+\varepsilon_{b, t}
\end{aligned}
$$

CIP is a dummy indicator taking the value of one if the CIP deviation (3 month Libor-based) is smaller than its mean value. Thus, $C I P=1$ indicates periods where borrowing via $\mathrm{FC}$ swaps is more expensive than obtaining foreign-currency funds directly. Our hypothesis is that a monetary policy shock, say in the US, reduces funding in USD for French and Italian banks. Having abundant EUR deposits, these banks could make up for the shortfall 
in USD funding by swapping EUR into USD in cross-currency swap markets. However, if this is costly (i.e. $C I P=1$ ), they will most likely cut their supply in USD lending.

The results are displayed in table 6. We first discuss the results for French banks. As shown in columns 1 and 2, adding CIP deviations to the regressions where the shock is identified using deposits from US residents (or, respectively, banks in the US) does not change any of the results and does not show any amplifying effect during times of tensions in cross-currency markets. However, when the monetary policy shock is identified using the total of USD cross-border funding (column 3), the interaction with the CIP dummy shows that the previously identified negative effect on USD lending is exacerbated during times of stress in currency swap markets. Thus, when monetary policy tightens, USD deposits (in the US and elsewhere) become more scarce. French banks are generally able to substitute into USD swap market funding. However, when cross-currency flows are large and hedging demand is high, this type of funding might become very costly (see Bräuning and Ivashina, 2017) and banks cut their USD lending. Our results are thus in line with the interpretation provided previously: monetary policy shocks transmit across borders and affect domestic lending when the supply of the concerned currency cannot be substituted for. As before, we do not find the same effects for GBP lending which we relate to the fact that the GBP does not constitute a funding currency for French banks to the same large extent as does the USD.

Nevertheless, in table 6 , we also observe some interesting cross-currency effects for the case of French banks. For example, columns 5 and 6 show that a US monetary tightening is associated with more GBP lending when there are no tensions in currency swap markets. However, one should keep in mind that the overall effect is not significant as shown in table 5. In terms of magnitudes, the results in table 6 are even stronger. The average French bank in the restricted sample has a USD funding dependence of $10.7 \%$; as a consequence, lending contracts by $15 \%(0.107 \times-1.148+0.107 \times-0.254)$ during times of stress in USD $/$ EUR swap markets.

Consistent with results from tables 4 and 5, foreign currency loans by Italian banks do not respond to US and UK monetary policy, even when taking into account tensions in swap currency markets. As table 6 shows, loans in USD and in GBP remain insulated by shifts in foreign monetary policy regardless of the reliance of funding from foreign sources even when deviations from covered interest parity are more pronounced. These findings are accounted for by the different use of foreign exchange options made in the two financial systems: according to a survey internationally coordinated by the Bank of International Settlements (BIS, 2016), the foreign exchange options accounted for $1 \%$ of turnover in the foreign exchange market for Italy and around $3 \%$ for France. 
Table 6: CIP deviations: effect on resident lending, by USD/GBP

\begin{tabular}{|c|c|c|c|c|c|c|}
\hline \multicolumn{7}{|c|}{ France } \\
\hline & \multicolumn{3}{|c|}{ Loans to residents in USD } & \multicolumn{3}{|c|}{ Loans to residents in GBP } \\
\hline & $\begin{array}{c}(1) \\
\text { Ctry } \\
\text { deposits }\end{array}$ & $\begin{array}{l}(2) \\
\text { Ctry deposit } \\
\text { to banks }\end{array}$ & $\begin{array}{l}(3) \\
\text { ts Deposits in } \\
\text { ctry currency }\end{array}$ & $\begin{array}{c}(4) \\
\text { Ctry } \\
\text { y deposits }\end{array}$ & $\begin{array}{l}(5) \\
\text { Ctry deposits } \\
\text { to banks }\end{array}$ & $\begin{array}{c}(6) \\
\text { ts Deposits in } \\
\text { ctry currenc }\end{array}$ \\
\hline Channel $\times$ MP US & $\begin{array}{c}-0.976^{* *} \\
{[0.033]}\end{array}$ & $\begin{array}{l}-0.603 \\
{[0.309]}\end{array}$ & $\begin{array}{l}-0.254^{* *} \\
{[0.041]}\end{array}$ & $\begin{array}{c}0.941 \\
{[0.380]}\end{array}$ & $\begin{array}{c}2.189^{* *} \\
{[0.024]}\end{array}$ & $\begin{array}{c}0.707^{* *} \\
{[0.045]}\end{array}$ \\
\hline Channel $\times$ MP UK & $\begin{array}{l}-0.110 \\
{[0.224]}\end{array}$ & $\begin{array}{l}-0.125 \\
{[0.188]}\end{array}$ & $\begin{array}{l}1.016 \\
{[0.277]}\end{array}$ & $\begin{array}{l}{\left[0.340^{*}\right.} \\
{[0.075]}\end{array}$ & $\begin{array}{c}-0.287^{*} \\
{[0.059]}\end{array}$ & $\begin{array}{l}1.673 \\
{[0.266]}\end{array}$ \\
\hline Channel $\times$ MP US $\times$ CIP USD & $\begin{array}{l}-0.204 \\
{[0.914]}\end{array}$ & $\begin{array}{c}0.729 \\
{[0.763]}\end{array}$ & $\begin{array}{l}-1.148^{* *} \\
{[0.028]}\end{array}$ & $\begin{array}{l}1.701 \\
{[0.649]}\end{array}$ & $\begin{array}{l}-1.014 \\
{[0.791]}\end{array}$ & $\begin{array}{l}-0.764 \\
{[0.282]}\end{array}$ \\
\hline Channel $\times$ MP UK $\times$ CIP GBP & {$\left[\begin{array}{l}0.230^{*} \\
0.079]\end{array}\right.$} & {$\left[0.300^{* *}\right.$} & $\begin{array}{l}-1.764 \\
{[0.116]}\end{array}$ & {$\left[0.367^{*}\right.$} & $\begin{array}{c}0.300 \\
{[0.110}\end{array}$ & $\begin{array}{l}-3.283^{*} \\
{[0.079]}\end{array}$ \\
\hline Channel $\times$ CIP USD & $\begin{array}{l}-0.305 \\
{[0.732]}\end{array}$ & $\begin{array}{l}0.131 \\
{[0.909]}\end{array}$ & $\begin{array}{l}-0.366 \\
{[0.250]}\end{array}$ & $\begin{array}{l}2.639^{*} \\
{[0.076]}\end{array}$ & $\begin{array}{c}2.053 \\
{[0.163]}\end{array}$ & $\begin{array}{c}0.097 \\
{[0.784]}\end{array}$ \\
\hline Channel $\times$ CIP GBP & $\begin{array}{l}-0.085 \\
{[0.238]}\end{array}$ & $\begin{array}{l}-0.073 \\
{[0.405]}\end{array}$ & $\begin{array}{l}-0.462 \\
{[0.517]}\end{array}$ & $\begin{array}{l}-0.165 \\
{[0.149]}\end{array}$ & $\begin{array}{l}-0.082 \\
{[0.557]}\end{array}$ & $\begin{array}{l}-1.046 \\
{[0.349]}\end{array}$ \\
\hline Channel US & $\begin{array}{l}-0.256 \\
{[0.299]}\end{array}$ & $\begin{array}{c}0.095 \\
{[0.769]}\end{array}$ & $\begin{array}{l}-0.155 \\
{[0.367]}\end{array}$ & $\begin{array}{l}-0.220 \\
{[0.782]}\end{array}$ & $\begin{array}{l}-0.645 \\
{[0.555]}\end{array}$ & $\begin{array}{l}-0.445 \\
{[0.179]}\end{array}$ \\
\hline Channel UK & $\begin{array}{c}0.107 \\
{[0.328]}\end{array}$ & $\begin{array}{c}0.101 \\
{[0.204]}\end{array}$ & $\begin{array}{l}-0.087 \\
{[0.837]}\end{array}$ & $\begin{array}{l}0.318^{* *} \\
{[0.024]}\end{array}$ & $\begin{array}{c}0.223^{*} \\
{[0.094]}\end{array}$ & $\begin{array}{l}0.761 \\
{[0.504]}\end{array}$ \\
\hline Observations & 2051 & 2053 & 2055 & 1031 & 1031 & 1032 \\
\hline$R^{2}$ & 0.12 & 0.12 & 0.13 & 0.14 & 0.13 & 0.14 \\
\hline Adjusted $R^{2}$ & 0.02 & 0.02 & 0.03 & -0.02 & -0.03 & -0.02 \\
\hline Number of banks & 125 & 125 & 125 & 83 & 83 & 83 \\
\hline \multicolumn{7}{|c|}{ Italy } \\
\hline & \multicolumn{3}{|c|}{ Loans to residents in USD } & \multicolumn{3}{|c|}{ Loans to residents in GBP } \\
\hline & $\begin{array}{c}(1) \\
\text { Ctry } \\
\text { deposits }\end{array}$ & $\begin{array}{c}(2) \\
\text { Ctry } \\
\text { deposits } \\
\text { to banks }\end{array}$ & $\begin{array}{c}(3) \\
\text { Deposits } \\
\text { in ctry } \\
\text { currency }\end{array}$ & $\begin{array}{c}\text { Ctry } \\
\text { deposits }\end{array}$ & $\begin{array}{c}(5) \\
\text { Ctry } \\
\text { deposits } \\
\text { to banks }\end{array}$ & $\begin{array}{c}(6) \\
\text { Deposits } \\
\text { in ctry } \\
\text { currency }\end{array}$ \\
\hline Channel $\times$ MP US & $\begin{array}{l}-0.231 \\
{[0.822]}\end{array}$ & $\begin{array}{c}2.373 \\
{[0.263]}\end{array}$ & {$\left[\begin{array}{l}0.111 \\
{[0.854]}\end{array}\right.$} & $\begin{array}{c}0.801 \\
{[0.817]}\end{array}$ & $\begin{array}{c}6.870 \\
{[0.267]}\end{array}$ & $\begin{array}{c}-0.107 \\
{[0.905]}\end{array}$ \\
\hline Channel $\times$ MP UK & $\begin{array}{l}-0.362 \\
{[0.581]}\end{array}$ & $\begin{array}{c}-0.333 \\
{[0.730]}\end{array}$ & $\begin{array}{c}0.493 \\
{[0.910]}\end{array}$ & $\begin{array}{c}2.215 \\
{[0.244]}\end{array}$ & $\begin{array}{l}-1.027 \\
{[0.712]}\end{array}$ & $\begin{array}{c}4.224 \\
{[0.568]}\end{array}$ \\
\hline Channel $\times$ MP US $\times$ CIP USD & $\begin{array}{c}6.994 \\
{[0.104]}\end{array}$ & $\begin{array}{c}4.447 \\
{[0.837]}\end{array}$ & $\begin{array}{l}-2.545 \\
{[0.488]}\end{array}$ & $\begin{array}{l}-3.229 \\
{[0.564]}\end{array}$ & $\begin{array}{r}-30.637 \\
{[0.558]}\end{array}$ & $\begin{array}{l}-5.775 \\
{[0.528]}\end{array}$ \\
\hline Channel $\times$ MP GB $\times$ CIP GBP & {$\left[\begin{array}{l}0.096 \\
{[0.892]}\end{array}\right.$} & $\begin{array}{c}0.121 \\
{[0.901]}\end{array}$ & $\begin{array}{c}1.542 \\
{[0.795]}\end{array}$ & $\begin{array}{l}-2.337 \\
{[0.279]}\end{array}$ & $\begin{array}{c}0.102 \\
{[0.974]}\end{array}$ & $\begin{array}{c}5.964 \\
{[0.741]}\end{array}$ \\
\hline Channel $\times$ CIP USD & $\begin{array}{c}2.829 \\
{[0.191]}\end{array}$ & $\begin{array}{c}1.182 \\
{[0.874]}\end{array}$ & $\begin{array}{l}-0.145 \\
{[0.904]}\end{array}$ & $\begin{array}{c}-4.777^{*} \\
{[0.095]}\end{array}$ & $\begin{array}{r}-15.819 \\
{[0.378]}\end{array}$ & $\begin{array}{l}-2.701 \\
{[0.561]}\end{array}$ \\
\hline Channel $\times$ CIP GBP & $\begin{array}{l}-0.755 \\
{[0.231]}\end{array}$ & $\begin{array}{l}-0.801^{* *} \\
{[0.036]}\end{array}$ & $\begin{array}{l}1.479 \\
{[0.748]}\end{array}$ & $\begin{array}{c}0.389 \\
{[0.827]}\end{array}$ & $\begin{array}{l}-0.843 \\
{[0.345]}\end{array}$ & $\begin{array}{l}-0.168 \\
{[0.991]}\end{array}$ \\
\hline Channel US & $\begin{array}{l}-0.133 \\
{[0.907]}\end{array}$ & $\begin{array}{l}2.179 \\
{[0.272]}\end{array}$ & $\begin{array}{l}-0.006 \\
{[0.985]}\end{array}$ & $\begin{array}{c}4.385 \\
{[0.148]}\end{array}$ & $\begin{array}{c}4.687 \\
{[0.441]}\end{array}$ & $\begin{array}{c}0.224 \\
{[0.814]}\end{array}$ \\
\hline Channel UK & $\begin{array}{c}0.502 \\
{[0.446]} \\
\end{array}$ & $\begin{array}{l}0.833^{* * *} \\
{[0.008]}\end{array}$ & $\begin{array}{c}0.744 \\
{[0.475]} \\
\end{array}$ & $\begin{array}{c}-0.939 \\
{[0.599]} \\
\end{array}$ & $\begin{array}{c}1.467 \\
{[0.159]} \\
\end{array}$ & $\begin{array}{c}2.320 \\
{[0.417]} \\
\end{array}$ \\
\hline Observations & 1694 & 1694 & 1694 & 698 & 698 & 698 \\
\hline$R^{2}$ & 0.30 & 0.30 & 0.30 & 0.24 & 0.25 & 0.22 \\
\hline Adjusted $R^{2}$ & 0.23 & 0.24 & 0.23 & 0.09 & 0.11 & 0.07 \\
\hline Number of banks & 52 & 52 & 52 & 28 & 28 & 28 \\
\hline
\end{tabular}

Notes: This table reports the regression results for the empirical specification in equation (2). The numbers represent the sum of coefficients on the monetary policy variables summed over the three lags and the contemporaneous variables. All regressions are OLS regressions; standard errors are clustered at bank level. P-values are reported in brackets. The transmission channel variable is reported in the column headers. 


\section{Concluding remarks}

This paper provides evidence on the impact of US and UK monetary policy shocks on domestic credit supply of French and Italian banks. Contrasting the experiences of France and Italy, we observe two countries within the Euro area where the international transmission of monetary policy through banks is quite different. Ex ante, the banking systems of these countries are similar in size and business model, yet they differ in the composition of funding sources and the currency composition of their funding as well as of loans granted.

In particular, we investigate whether lending to residents responds differently to foreign monetary policy depending on the degree of exposure of banks' funding from the foreign countries where monetary policy changes. We find evidence of an international bank lending channel of transmission of US monetary policy for loans to French and Italian residents over the period 2000-2015: in both countries, when US monetary policy tightens, banks that relied more intensely on US sources of funding reduced the lending to the private nonfinancial sector. The breakdown by currency shows that in the case of Italy the effect was concentrated on loans in EUR whereas French banks reduced their USD lending. Also, the impact is larger for French banks that relied more heavily on USD funding markets and that obtained substantial amounts of USD funds through their affiliate network in the US. Tensions in currency swap markets in recent years have exacerbated this effect. Our results are consistent with the hypothesis that funding in one currency is not a perfect substitute for funding in another currency, especially in the case of the USD.

We do not find much of an effect of UK monetary policy shocks on domestic lending in France nor Italy. Despite the fact that exposure to the UK is larger than to the US for both French and Italian banks, they seem to be isolated from UK monetary policy shocks given that most of their UK funding is not denominated in GBP. 


\section{References}

ACPR (2017): Chiffres du marché français de la banque et de l'assurance. Available at: https://acpr.banque-france.fr/fileadmin/user_upload/acp/publications/rapportsannuels/20170106-Rapport-chiffres-ACPR-2015.pdf.

Adrian, Tobias and Hyun Song Shin (2008): Financial intermediaries, financial stability, and monetary policy. Staff Reports 346, Federal Reserve Bank of New York.

Aizenman, Joshua, Menzie D. Chinn and Hiro Ito (2016): Monetary policy spillovers and the trilemma in the new normal: Periphery country sensitivity to core country conditions. Journal of International Money and Finance, 68(C), pp. 298-330.

Avdjiev, Stefan, Wenxin Du, Catherine Koch and Hyun Song Shin (2016): The dollar, bank leverage and the deviation from covered interest parity. BIS Working Papers 592, Bank for International Settlements.

Bauer, Michael D. and Glenn D. Rudebusch (2014): The Signaling Channel for Federal Reserve Bond Purchases. International Journal of Central Banking, 10(3), pp. 233-289.

Bernanke, Ben S and Alan S Blinder (1988): Credit, Money, and Aggregate Demand. American Economic Review, 78(2), pp. 435-439.

Bernanke, Ben S. and Mark Gertler (1995): Inside the Black Box: The Credit Channel of Monetary Policy Transmission. Journal of Economic Perspectives, 9(4), pp. 27-48.

Bhattarai, Saroj, Arpita Chatterjee and Woong Yong Park (2015): Effects of US quantitative easing on emerging market economies. Globalization and Monetary Policy Institute Working Paper 255, Federal Reserve Bank of Dallas.

BIS (2016): Triennial Central Bank Survey: Foreign exchange turnover in April 2016. April 2016, Bank of International Settlements.

Bluwstein, Kristina and Fabio Canova (2016): Beggar-Thy-Neighbor? The International Effects of ECB Unconventional Monetary Policy Measures. International Journal of Central Banking, 12(3), pp. 69-120.

Bofondi, Marcello, Luisa Carpinelli and Enrico Sette (2017): Credit Supply During a Sovereign Debt Crisis. Journal of the European Economic Association. Forthcoming.

Borio, Claudio, Robert Neil McCauley, Patrick McGuire and Vladyslav Sushko (2016): Covered interest parity lost: understanding the cross-currency basis. BIS Quarterly Review.

Bräuning, Falk and Victoria Ivashina (2017): Monetary Policy and Global Banking. NBER Working Papers 23316, National Bureau of Economic Research.

Bruno, Valentina and Hyun Song Shin (2015): Capital flows and the risk-taking channel of monetary policy. Journal of Monetary Economics, 71(C), pp. 119-132.

Buch, Claudia M, Matthieu Bussière, Linda S Goldberg and Robert Hills (2018): The International Transmission of Monetary Policy. Working Paper 24454, NBER. 
Buch, Claudia M and Linda S Goldberg (2017): Cross-Border Prudential Policy Spillovers: How Much? How Important? Evidence from the International Banking Research Network. International Journal of Central Banking, 13(2), pp. 505-558.

Caccavaio, Marianna, Luisa Carpinelli, Giuseppe Marinelli and Enrico Sette (2015): International Banking and Liquidity Risk Transmission: Evidence from Italy. IMF Economic Review, 63(3), pp. 568-584.

Carpinelli, Luisa and Matteo Crosignani (2017): The Effect of Central Bank Liquidity Injections on Bank Credit Supply. Mimeo.

Cetorelli, Nicola and Linda S. Goldberg (2012): Banking Globalization and Monetary Transmission. Journal of Finance, 67(5), pp. 1811-1843.

Correa, Ricardo, Teodora Paligorova, Horacio Sapriza and Andrei Zlate (2017): CrossBorder Bank Flows and Monetary Policy: Implications for Canada. Staff Working Papers 17-34, Bank of Canada.

Demirguc-Kunt, Asli, Balint Horvath and Harry Huizinga (2017): Foreign Banks and International Transmission of Monetary Policy: Evidence from the Syndicated Loan Market. CEPR Discussion Papers 11796, CEPR Discussion Papers.

Du, Wenxin, Alexander Tepper and Adrien Verdelhan (2017): Deviations from Covered Interest Rate Parity. Working Paper 23170, National Bureau of Economic Research.

ECB (2017): Report on financial structures. October 2017, European Central Bank.

Falagiarda, Matteo, Peter McQuade and Marcel Tirpák (2015): Spillovers from the ECB's non-standard monetary policies on non-euro area EU countries: evidence from an eventstudy analysis. Working Paper Series 1869, European Central Bank.

Fratzscher, Marcel, Marco Lo Duca and Roland Straub (2016): ECB Unconventional Monetary Policy: Market Impact and International Spillovers. IMF Economic Review, 64(1), pp. $36-74$.

Fratzscher, Marcel, Roland Straub and Marco Lo Duca (2013): On the international spillovers of US quantitative easing. Working Paper Series 1557, European Central Bank.

Georgiadis, Georgios (2015): Determinants of global spillovers from US monetary policy. Working Paper Series 1854, European Central Bank.

Ivashina, Victoria, David S. Scharfstein and Jeremy C. Stein (2015): Dollar Funding and the Lending Behavior of Global Banks. The Quarterly Journal of Economics, 130(3), pp. $1241-1281$.

Jiménez, Gabriel, Steven Ongena, José-Luis Peydró and Jesús Saurina (2014): Hazardous Times for Monetary Policy: What Do Twenty-Three Million Bank Loans Say About the Effects of Monetary Policy on Credit Risk-Taking? Econometrica, 82(2), pp. 463-505.

Kashyap, Anil K. and Jeremy C. Stein (1994): Monetary Policy and Bank Lending. In: Monetary Policy, NBER Chapters, pp. 221-261. National Bureau of Economic Research. 
Kashyap, Anil K. and Jeremy C. Stein (1997): The role of banks in monetary policy: a survey with implications for the European Monetary Union. Economic Perspectives, (Sep), pp. 2-18.

Krippner, Leo (2016): Documentation for measures of monetary policy. Mimeo.

McCauley, Robert N., Patrick McGuire and Vladyslav Sushko (2015): Global dollar credit: links to US monetary policy and leverage. Economic Policy, 30(82), pp. 187-229.

Morais, Bernardo, José-Luis Peydró and Claudia Ruiz Ortega (2017): The International Bank Lending Channel of Monetary Policy Rates and QE: Credit Supply, Reach-forYield, and Real Effects. Journal of Finance. Forthcoming.

Ongena, Steven, Ibolya Schindele and Dzsamila Vonnák (2017): In Lands of Foreign Currency Credit, Bank Lending Channels Run Through? MNB Working Papers 2017/6, Magyar Nemzeti Bank (Central Bank of Hungary).

Shin, Hyun Song (2012): Global Banking Glut and Loan Risk Premium. IMF Economic Review, 60(2), pp. 155-192.

Takats, Elod and Judit Temesvary (2017): The Currency Dimension of the Bank Lending Channel in International Monetary Transmission. Finance and Economics Discussion Series 2017-001, Board of Governors of the Federal Reserve System (U.S.).

Temesvary, Judit, Steven Ongena and Ann L. Owen (2015): A Global Lending Channel Unplugged? Does U.S. Monetary Policy Affect Cross-border and Affiliate Lending by Global U.S. Banks? MPRA Paper 65913, University Library of Munich, Germany. 


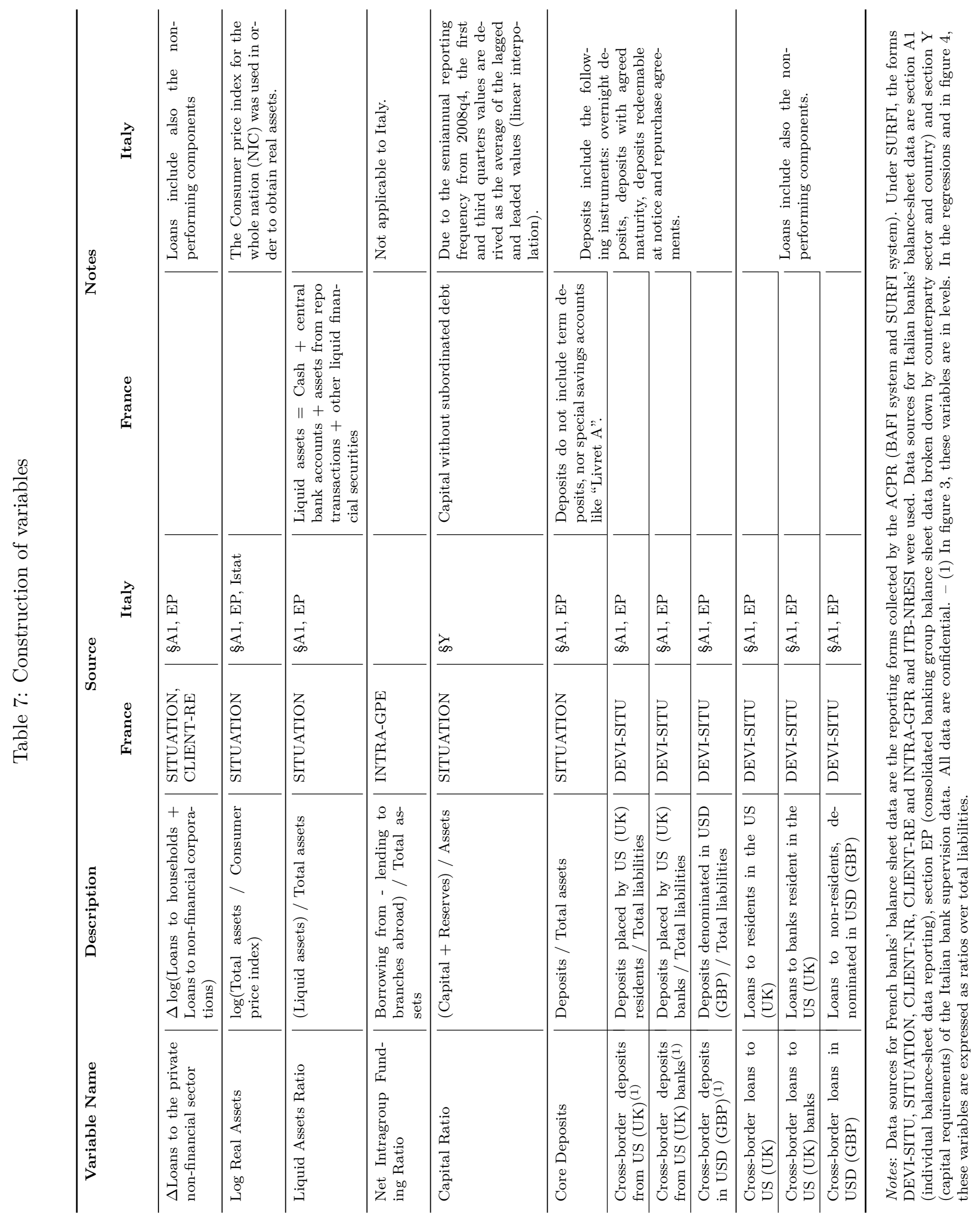

